Atmos. Chem. Phys., 19, 10537-10555, 2019

https://doi.org/10.5194/acp-19-10537-2019

(C) Author(s) 2019. This work is distributed under

the Creative Commons Attribution 4.0 License.

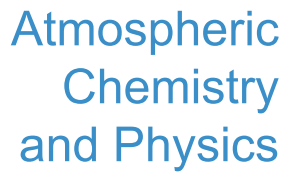

(c) (P)

\title{
New particle formation, growth and apparent shrinkage at a rural background site in western Saudi Arabia
}

\author{
Simo Hakala ${ }^{1}$, Mansour A. Alghamdi ${ }^{2}$, Pauli Paasonen ${ }^{1}$, Ville Vakkari ${ }^{3,4}$, Mamdouh I. Khoder $^{2}$, Kimmo Neitola $^{1}$, \\ Lubna Dada $^{1}$, Ahmad S. Abdelmaksoud ${ }^{2}$, Hisham Al-Jeelani ${ }^{2}$, Ibrahim I. Shabbaj ${ }^{2}$, Fahd M. Almehmadi ${ }^{2}$, \\ Anu-Maija Sundström ${ }^{3}$, Heikki Lihavainen ${ }^{3,5}$, Veli-Matti Kerminen ${ }^{1}$, Jenni Kontkanen ${ }^{1}$, Markku Kulmala ${ }^{1,6}$, \\ Tareq Hussein ${ }^{1}$, and Antti-Pekka Hyvärinen ${ }^{3}$ \\ ${ }^{1}$ Institute for Atmospheric and Earth System Research (INAR)/Physics, Faculty of Science, University of \\ Helsinki, Helsinki, Finland \\ ${ }^{2}$ Department of Environmental Sciences, Faculty of Meteorology, Environment and Arid Land Agriculture, King Abdulaziz \\ University, Jeddah, Saudi Arabia \\ ${ }^{3}$ Finnish Meteorological Institute, Helsinki, Finland \\ ${ }^{4}$ Unit for Environmental Sciences and Management, North-West University, 2520 Potchefstroom, South Africa \\ ${ }^{5}$ Svalbard Integrated Arctic Earth Observing System (SIOS), Longyearbyen, Norway \\ ${ }^{6}$ Aerosol and Haze Laboratory, Beijing Advanced Innovation Center for Soft Matter Science and Engineering, Beijing \\ University of Chemical Technology, Beijing, China
}

Correspondence: Simo Hakala (simo.hakala@helsinki.fi)

Received: 28 December 2018 - Discussion started: 20 February 2019

Revised: 13 June 2019 - Accepted: 25 June 2019 - Published: 21 August 2019

\begin{abstract}
Atmospheric aerosols have significant effects on human health and the climate. A large fraction of these aerosols originates from secondary new particle formation (NPF), where atmospheric vapors form small particles that subsequently grow into larger sizes. In this study, we characterize NPF events observed at a rural background site of Hada Al Sham $\left(21.802^{\circ} \mathrm{N}, 39.729^{\circ} \mathrm{E}\right)$, located in western Saudi Arabia, during the years 2013-2015. Our analysis shows that NPF events occur very frequently at the site, as $73 \%$ of all the 454 classified days were NPF days. The high NPF frequency is likely explained by the typically prevailing conditions of clear skies and high solar radiation, in combination with sufficient amounts of precursor vapors for particle formation and growth. Several factors suggest that in Hada Al Sham these precursor vapors are related to the transport of anthropogenic emissions from the coastal urban and industrial areas. The median particle formation and growth rates for the NPF days were $8.7 \mathrm{~cm}^{-3} \mathrm{~s}^{-1}\left(J_{7 \mathrm{~nm}}\right)$ and $7.4 \mathrm{~nm} \mathrm{~h}^{-1}$ $\left(\mathrm{GR}_{7-12 \mathrm{~nm}}\right)$, respectively, both showing highest values during late summer. Interestingly, the formation and growth rates increase as a function of the condensation sink, likely reflecting the common anthropogenic sources of NPF pre-
\end{abstract}

cursor vapors and primary particles affecting the condensation sink. A total of $76 \%$ of the NPF days showed an unusual progression, where the observed diameter of the newly formed particle mode started to decrease after the growth phase. In comparison to most long-term measurements, the NPF events in Hada Al Sham are exceptionally frequent and strong both in terms of formation and growth rates. In addition, the frequency of the decreasing mode diameter events is higher than anywhere else in the world.

\section{Introduction}

The effect of atmospheric aerosols on the Earth's radiative balance, via scattering, absorption and cloud interactions, is the single largest factor limiting our understanding of future and past climate changes (Stocker et al., 2013). In addition to the climate effects, aerosols are known to be detrimental to human health, with outdoor particulate pollution being the cause of more than 3 million premature deaths in the year 2010 (Lelieveld et al., 2015). These effects include the contribution of both primary and secondary aerosol par- 
ticles. Primary particles are emitted into the atmosphere directly as particles, while secondary particles are formed from atmospheric vapors in new particle formation (NPF) events. Measurements of submicron particle number size distributions (PNSDs) have shown that NPF events are a global phenomenon (Kulmala et al., 2004), and they are estimated to produce around half $(31 \%-66 \%)$ of the cloud condensation nuclei $(\mathrm{CCN})$ in the lower troposphere (Yu and Luo, 2009; Merikanto et al., 2009; Gordon et al., 2017). Even in polluted regions, where the primary emissions are high, NPF events are found to occur frequently (Yu et al., 2017), and they are estimated to be a significant contributor to the particle number concentrations (Yue et al., 2011; Kulmala et al., 2016; Yao et al., 2018). Despite the importance of NPF, many aspects related to the initial formation and subsequent growth of secondary aerosol particles remain unknown. While sulfuric acid is widely regarded as the most important precursor for NPF, it is clear that other compounds are needed to explain particle formation and growth rates in ambient measurements, especially in the boundary layer (Kirkby et al., 2011; Ehrhart et al., 2016). Stabilizing bases, such as ammonia and dimethylamine, low-volatility oxidation products of VOCs (volatile organic compounds) and ions have been shown to enhance particle formation rates and bridge some of the gaps between theoretical evaluations, laboratory studies and ambient measurements (H. Yu et al., 2012; F. Yu et al., 2018; Almeida et al., 2013; Kürten et al., 2014, 2016, 2018; Zhang et al., 2004; Riccobono et al., 2014). The initial particle-forming compounds will also participate in growing the particles, but, in order to explain the observed growth rates, the presence of more abundant condensing (or otherwise particle mass forming, for example, via heterogeneous oligomer formation) species is required (Nieminen et al., 2010; Riccobono et al., 2012). These species are very likely to be low-volatility or semivolatile organic compounds, formed by the oxidation of either biogenic or anthropogenic VOCs (Smith et al., 2008; Tröstl et al., 2016; Dall'Osto et al., 2018). Overall, the mixture of compounds and the relative importance of different species participating in aerosol formation and growth are expected to vary depending on the ambient conditions; in some coastal environments NPF can be driven by iodine compounds (Sipilä et al., 2016), and, for example, in urban areas the uptake of nitrate can contribute significantly to aerosol mass (Li et al., 2018). Predicting all the occurring interactions in the atmosphere is impossible without observations from several different environments. While PNSD measurements have been conducted in a wide range of environments (Kerminen et al., 2018), especially continuous long-term measurements are still fairly uncommon and largely focused on Europe and the midlatitudes (Nieminen et al., 2018). Long-term measurements are needed for obtaining reliable estimates on the average properties and seasonal tendencies of atmospheric NPF. Such data are essential in evaluating the performance of global models, which currently have large uncertainties in simulating atmospheric NPF, as well as its contribution to $\mathrm{CCN}$ budgets and aerosol radiative effects in different environments (Pierce and Adams, 2009; Makkonen et al., 2012; Gordon et al., 2016; Semeniuk and Dastoor, 2018).

Recently, several NPF studies have pointed out an interesting phenomenon, where the average diameter of the particle mode formed in an NPF event begins to decrease after the growth phase. This is often referred to as aerosol shrinkage, but we will use the term DMD (decreasing mode diameter) event, since aerosol shrinkage quite directly implies a reduction in the size of individual particles, which is not necessarily the case. Such DMD events have been observed especially in subtropical regions (Yao et al., 2010; Backman et al., 2012; Cusack et al., 2013; Young et al., 2013; Zhang et al., 2016; Alonso-Blanco et al., 2017) but also in the temperate climate (Skrabalova, 2015; Salma et al., 2016). Typically, these DMD events are suggested to be caused by the evaporation of semivolatile compounds, due to changes in environmental conditions. However, the reduction in the mean diameter of a particle mode may also occur without evaporation, if smaller particles are transported to the measurement site (Kivekäs et al., 2016).

In this paper, we study the aerosol particle number size distribution dynamics at Hada Al Sham, Saudi Arabia, during February 2013-February 2015. The environment is quite unique due to high anthropogenic and low biogenic emissions, as well as a distinct segregation between the surroundings in different directions. To our knowledge, these are the first comprehensive long-term aerosol measurements conducted in the Arabian Peninsula. Two articles from the same measurement campaign are already published, describing the aerosol physical (Lihavainen et al., 2016) and optical properties (Lihavainen et al., 2017). The former article also contains analysis of particle number concentrations, which will not be presented in this study. This work focuses on identifying and characterizing NPF in the study region. We show that the NPF events in Hada al Sham are, in comparison to the locations analyzed in the exhaustive study by Nieminen et al. (2018), exceptionally frequent and intense, in terms of both particle formation and growth rates. We also make a detailed investigation of the typical diurnal cycle related to the NPF events and determine how the events are impacted by different environmental variables, including meteorological conditions and the concentrations and sources of primary aerosol particles and aerosol precursor compounds.

\section{Measurements and methods}

\subsection{Measurement site and instrumentation}

Hada $\mathrm{Al} \mathrm{Sham}\left(21.802^{\circ} \mathrm{N}, 39.729^{\circ} \mathrm{E} ; 254 \mathrm{~m}\right.$ a.s.l.) is a small city in western Saudi Arabia (see Fig. 3). There are no major sources of anthropogenic emissions in the immediate vicinity, and the site can be described as a rural background site. 
Biogenic emissions are also presumably minor due to the arid desert climate and lack of vegetation. Sparsely inhabited desert-like areas cover the inland in the N-SE direction from the measurement site, but the coastal regions in the western sector are densely populated. Jeddah, the second largest city in Saudi Arabia, is located by the Red Sea $\sim 60 \mathrm{~km}$ to the west from Hada Al Sham. In Jeddah there are several major emission sources, including power-generation plants, a seawater desalination plant, and an airport and a harbor, both of which experience heavy traffic due to the combined effect of economic growth and the vicinity of Mecca (also known as Makkah) located $\sim 40 \mathrm{~km}$ to the south from Hada Al Sham. Other major emission sources in the region include a petrochemical refinery and steel industry in Rabigh $(\sim 130 \mathrm{~km}$ NW; see Fig. 3) and a large oil refinery in Yanbu $(\sim 290 \mathrm{~km}$ NW). The densely populated coastal region and the sparsely populated inland are separated by mountains running along the coast of the Red Sea. Hada Al Sham is located by the western slopes of these mountains and is thus topographically more connected to the coastal region.

The measurements were conducted at the Agricultural Research Station of King Abdulaziz University from February 2013 to February 2015. The instruments were placed inside a container, located on a sand field, with a distance of $\sim 100 \mathrm{~m}$ to the nearest trees and other obstacles. The temperature was kept stable inside the container at $\sim 25^{\circ} \mathrm{C}$. The sample air inlets were located at a height of 4-4.5 $\mathrm{m}$ and the sample air flow rate was $16.7 \mathrm{~L} \mathrm{~min}^{-1}$. A more thorough description of the measurement setup and the used instruments can be found in Lihavainen et al. (2016). In this study, we focus on the PNSD measurements in the mobility diameter range of 7-850 $\mathrm{nm}$, obtained using a twin DMPS (differential mobility particle sizer; Wiedensohler et al., 2012), and the meteorological parameters (temperature, relative humidity, wind speed and wind direction), which were measured with a Vaisala WXT weather station. The twin DMPS used here consists of a short and a medium Hauke-type DMA (differential mobility analyzer, custom-made) and two CPCs (condensation particle counter, TSI 3772). To study the effects of mineral dust, we utilized the PNSDs in the aerodynamic diameter range of $0.5-10 \mu \mathrm{m}$, measured with an APS (aerodynamic particle sizer, TSI 3321), and the mass of particles smaller than $10 \mu \mathrm{m}\left(\mathrm{PM}_{10}\right)$, measured with a beta hybrid mass monitor (Thermo Scientific 5030). The inlet leading to the DMPS and the APS was equipped with a PM $_{10}$ filter and a twin diffusion dryer, which kept the sample air relative humidity mainly below $50 \%$. PNSD measurements were corrected for diffusional losses in the inlet line and they were at maximum around $15 \%$ at the lower size limit of the DMPS. The $\mathrm{PM}_{10}$ measurements were made from a separate inlet, equipped with a standard heater for sample drying. Since no gas-phase measurements were conducted during this campaign, we used data from the Ozone Monitoring Instrument (OMI) on board NASA's Aura satellite (Levelt et al., 2006) to estimate the $\mathrm{SO}_{2}$ concentrations (OMI Level $2 \mathrm{SO}_{2}$ plane-

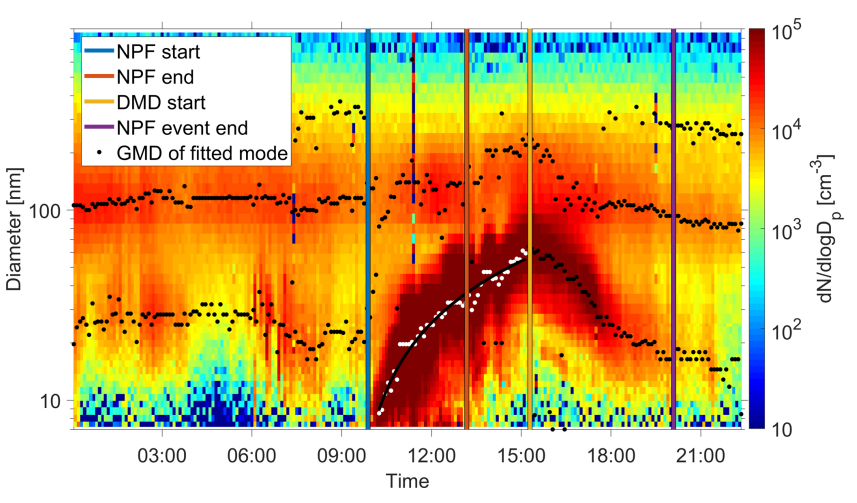

Figure 1. Particle number size distribution measured by DMPS showing an NPF event with a decreasing mode mean diameter (after 15:00 LT; UTC+3) in Hada Al Sham on 3 February 2014. The figure also illustrates the times describing the progression of the NPF events with colored vertical lines (NPF start - blue, NPF end - orange, DMD start - yellow, and NPF event end - purple) and the geometric mean diameters (GMDs) of fitted modes with black circles. The GMDs selected for the calculation of the growth rate are shown using white circles, and the black curve shows the linear fit to these points.

tary boundary layer product; Li et al., 2013) at Hada Al Sham and its surroundings.

\subsection{NPF event classification}

NPF event classification was done for the measurement days based on the visual interpretation of PNSDs, as described by Dal Maso et al. (2005). Each day was classified as either (1) an NPF day, (2) a nonevent day or (3) undefined. In short, a day is classified as an NPF day if a new growing mode of particles appears in the nucleation mode $\left(d_{\mathrm{p}}<25 \mathrm{~nm}\right)$ and the growing mode is observed to persist for several hours (see Fig. 1 for an example of an NPF day and Fig. A1 for time series of PNSDs from selected periods). If some, but not all, of the abovementioned criteria are fulfilled, the day is classified as undefined. In addition, a day is classified as undefined if the time development of the newly formed particle mode is highly erratic, or if the mode is not continuous due to significant breaks. Only the days when there is clearly no indication of NPF are classified as nonevent days.

As an addition to the traditional classification, each NPF day was further classified based on whether the mean diameter of the mode formed in the NPF event clearly starts to decrease after the growth phase (see Fig. 1) or not. These days are referred to as DMD days and non-DMD days, respectively.

\subsubsection{Event times}

To describe the progression of the NPF events, we determined the points in time when (1) NPF is first observed in the smallest size bins of the DMPS measurements, (2) NPF 
is no longer observed, (3) the mode diameter of the newly formed particles starts to decrease and (4) the mode formed in the NPF event is no longer distinguishable from the background aerosols due to decreased number concentrations or, for example, changes in air masses. These times were determined visually from the PNSDs, and they are referred to as NPF start, NPF end, DMD start and NPF event end, respectively (Fig. 1). NPF start times were only determined for the days when NPF was observed all the way from the smallest size bins, and the NPF event end times were only determined for the days when the event ended during the same day as NPF had started.

\subsection{Determination of particle formation and growth rates}

The formation and growth rates of newly formed particles are important quantities in describing NPF (Kulmala et al., 2012). They provide information on the strength of the NPF events and are closely connected to the atmospheric factors driving the process, such as the concentrations of condensable vapors. The growth rates of freshly formed particles have a critical role in their probability to survive into climaterelevant sizes, as particles that grow too slowly are removed by coagulation with larger preexisting particles (Kuang et al., 2009).

In this study, the particle growth rates were determined by following the time development of the geometric mean diameters (GMDs) obtained from lognormal fits to the PNSD at each measurement time. The fitting was done using an automatic algorithm developed by Hussein et al. (2005), which analyses the measured PNSD, fits 2-3 lognormal modes and returns the fitting parameters. In practice, the growth rates are determined by plotting the GMDs of fitted modes together with the PNSD and making a linear fit to the points selected to represent the mode formed in the NPF event (Fig. 1). Now, the diameter growth rate (GR) in the size range $\Delta d_{\mathrm{m}}$ can be calculated simply as the slope of the fitted line:

$\mathrm{GR}_{\Delta d_{\mathrm{m}}}=\frac{\Delta d_{\mathrm{m}}}{\Delta t}$

where $\Delta d_{\mathrm{m}}$ is the change in the geometric mean diameter during the time interval $\Delta t$. The growth rates presented in this study were determined so that they would best describe the growth of particles in the diameter range $7-12 \mathrm{~nm}$, as this is the range used in the determination of the formation rates. In principle, this could be done by only selecting the GMD points below $12 \mathrm{~nm}$, but since single points are subject to fluctuations in the PNSD, and the number of fitted points below the $12 \mathrm{~nm}$ threshold was often quite small, points above $12 \mathrm{~nm}$ were often included into the fit to obtain a more robust estimate of the particle growth. This was, however, done only if the growth rate seemed to remain constant above the $12 \mathrm{~nm}$ threshold.
The formation rate $(J)$ of particles with diameter $d_{\mathrm{p}}$ can be determined using the equation (Kulmala et al., 2004)

$J_{d_{\mathrm{p}}}=\frac{\mathrm{d} N_{\Delta d_{\mathrm{p}}}}{\mathrm{d} t}+\operatorname{CoagS}_{\Delta d_{\mathrm{p}}} N_{\Delta d_{\mathrm{p}}}+\frac{\mathrm{GR}_{\Delta d_{\mathrm{p}}}}{\Delta d_{\mathrm{p}}} N_{\Delta d_{\mathrm{p}}}$,

where $N_{\Delta d_{\mathrm{p}}}$ is the number concentration and CoagS ${ }_{\Delta d_{\mathrm{p}}}$ is the coagulation sink (Sect. 2.4) of the particles in the size range $\Delta d_{\mathrm{p}}$. Therefore, the formation rate is defined as the flux of particles past the lower limit of the size range, and it is obtained by adding up the change in the observed particle number concentration with the losses of particles due to coagulation and growth out of the size range. In this study, we calculated the formation rate of $7 \mathrm{~nm}$ particles using the diameter range $7-12 \mathrm{~nm}$.

\subsection{Calculation of coagulation and condensation sinks}

The coagulation sink describes the rate at which particles are lost due to collision and coalescence with larger particles. The collisions can occur due to differing settling velocities, turbulence, electric interactions or Brownian motion. However, when describing the coagulation of submicron particles in typical atmospheric conditions, the coagulation due to Brownian motion is by far the most significant. When only this mechanism is considered, the coagulation sink can be calculated by integrating over the PNSD (Kulmala et al., 2001):

$$
\begin{aligned}
\operatorname{CoagS}_{d_{\mathrm{p}}} & =\int K\left(d_{\mathrm{p}}, d_{\mathrm{p}}^{\prime}\right) n\left(d_{\mathrm{p}}^{\prime}\right) \mathrm{d} d_{\mathrm{p}}^{\prime} \\
& =\sum_{d_{\mathrm{p}, i}^{\prime}=d_{\mathrm{p}}}^{d_{\mathrm{p}, \max }} K\left(d_{\mathrm{p}}, d_{\mathrm{p}, i}^{\prime}\right) N_{d_{\mathrm{p}, i}^{\prime}},
\end{aligned}
$$

where $K\left(d_{\mathrm{p}}, d_{\mathrm{p}}^{\prime}\right)$ is the coagulation coefficient (Seinfeld and Pandis, 1998; Fuchs, 1964), which describes the probability of particles with diameters $d_{\mathrm{p}}$ and $d_{\mathrm{p}}^{\prime}$ to collide. This coefficient is proportional to the particle surface area and it increases with increasing size difference between the colliding particles. Both the coagulation sink of nucleation mode particles and the condensation sink are largely determined by the Aitken and accumulation mode particles that typically dominate the total particle surface area. The coagulation and condensation sinks were calculated using the DMPS measurements, which sets the upper diameter limit $\left(d_{\mathrm{p}, \max }\right)$ of particles included in the calculation at $850 \mathrm{~nm}$. In the calculation of the coagulation sink, we used the geometric mean of the diameter range $(7-12 \mathrm{~nm})$ to approximate the size of coagulating particles.

The condensation sink (CS) describes the ability of the aerosol population to remove condensable vapors from the atmosphere. The concept is analogous to the coagulation sink, defined with Eq. (3), but now, instead of the particle loss rate, the rate at which vapors condense onto preexisting 
aerosol particles is considered. Similarly to the coagulation sink, the CS is calculated by integrating over the PNSD (Kulmala et al., 2001):

$$
\begin{aligned}
\mathrm{CS} & =2 \pi D \int d_{\mathrm{p}} \beta_{m}\left(d_{\mathrm{p}}\right) n\left(d_{\mathrm{p}}\right) \mathrm{d} d_{\mathrm{p}} \\
& =2 \pi D \sum_{d_{\mathrm{p}, i}=d_{\mathrm{p}, \min }}^{d_{\mathrm{p}, \max }} \beta_{m}\left(d_{\mathrm{p}, i}\right) d_{\mathrm{p}, i} N_{i},
\end{aligned}
$$

where $D$ is the diffusion coefficient of the condensing vapor and $\beta_{m}$ is the correction coefficient for the transitional regime (Fuchs and Sutugin, 1970). Here, the CS is calculated using the properties of sulfuric acid as the condensing vapor. In practice, this means that the CS describes the loss rate of such vapors that condense irreversibly onto the particles upon each collision.

\subsection{Air mass history}

Air mass history was studied by calculating particle retroplumes using a Lagrangian particle dispersion model FLEXPART (FLEXible PARTicle dispersion model) version 9.02 (Stohl et al., 2005). ECMWF (European Centre for MediumRange Weather Forecast) operational forecast with $0.15^{\circ}$ horizontal and $1 \mathrm{~h}$ temporal resolution was used as the meteorological input into the model. The number of height levels in the meteorological data was 91 before 25 June 2013 and 137 after that.

The model was run for a time period from February 2013 to May 2014. During this period, a new release of 50000 model particles, distributed evenly between 0 and $100 \mathrm{~m}$ above the measurement site, occurred every $1 \mathrm{~h}$. The released particles were traced backwards in time for $72 \mathrm{~h}$, unless they exceeded the model grid $\left(0-45^{\circ} \mathrm{N}, 15-70^{\circ} \mathrm{E}\right.$; resolution: $0.05^{\circ}$ ). The model time step was $10 \mathrm{~min}$, but, in the calculation of turbulent wind components, the use of a shorter time step, determined internally by the model, was allowed. The parametrization of moist convection was also set on to improve the quality of the model run. Particle wet and dry deposition were not considered, since in this work the model is only used to study the movements of air masses.

The model output was saved every $1 \mathrm{~h}$ and, in relevance to this study, it contains (1) the emission sensitivity field, i.e., a matrix whose values are proportional to the time the model particles have spent over each grid point during the last hour; and (2) a point of the average trajectory that is determined by cluster analysis (Seibert and Frank, 2004) from the locations of the model particles. In addition, we use the atmospheric boundary layer (ABL) height at Hada $\mathrm{Al} \mathrm{Sham,}$ obtained from the ECMWF operational forecast.

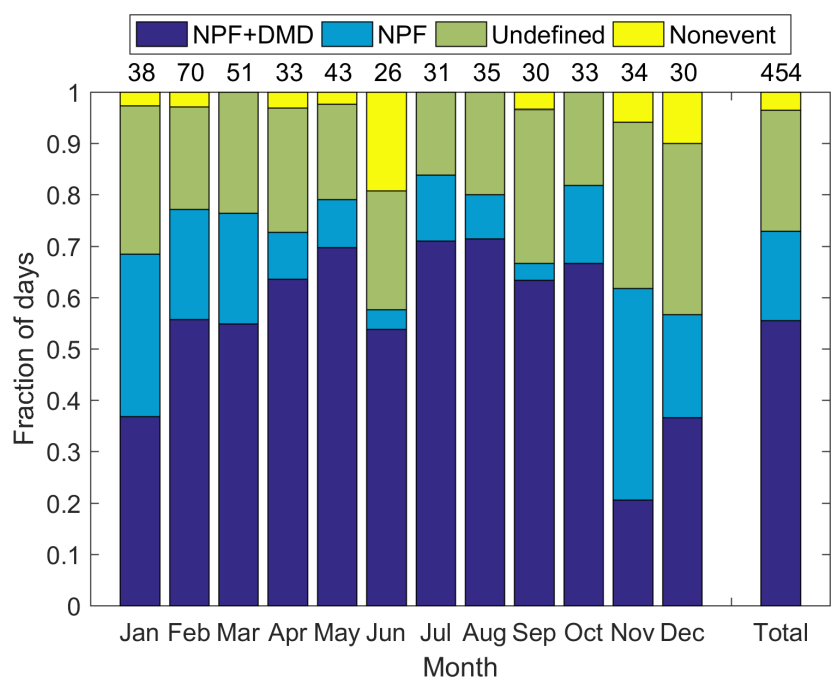

Figure 2. Results of the NPF event classification as fractions of classified days, separately for each month and all of the classified days. The numbers above the bars show the number of classified days. Some of the months contain days from more than a year, while in some months (June, July, September and December) data were available only for a single year.

\section{Results and discussion}

\subsection{NPF event frequency}

The results of the NPF event classification are presented in Fig. 2. The total NPF event frequency was found to be very high, as $73 \%$ of all the classified days (454) were NPF days. Out of the NPF days, $76 \%$ were DMD days, meaning that only about one quarter of the NPF events showed monotonic growth, which is the typical progression of NPF in most environments. Only $4 \%$ of the days were classified as nonevents, leaving $23 \%$ as undefined. It should be noted that the majority of the undefined days were likely days when new particles were formed, but continuous growth of particles was not observed at Hada Al Sham due to unfavorable meteorological conditions (referred to as "failed events" by Buenrostro Mazon et al., 2009).

The monthly fractions in Fig. 2 show that the NPF frequency is high $(55 \%-85 \%)$ throughout the year and that no clear seasonal pattern is observed. This implies that the NPF events are not limited by any factor with a strong seasonal variability. The most notable deviations from the average frequency are found in June, November and December, which all have a higher-than-average fraction of nonevent days. Although no seasonal cycle is seen in the total NPF frequency, the DMD events are more frequent during the summer (and autumn) months and less frequent during winter. The fraction of DMD events from all NPF days is highly variable, ranging from $33 \%$ in November to $95 \%$ in September. 
The average NPF event frequency of $73 \%$ in Hada Al Sham is among the highest event frequencies obtained from long-term measurements. Nieminen et al. (2018) compared PNSD measurements, consisting of at least 1 full year of data, conducted at 36 different sites around the world. They observed that NPF events are most frequent in South Africa, where the NPF frequencies from three different sites were $69 \%, 75 \%$ and $86 \%$ (Hirsikko et al., 2012; Vakkari et al., 2011, 2015). Thus, the NPF fraction of $73 \%$ obtained from the measurements presented here would take the third place in this global comparison. The high NPF event frequency is a direct indication of typically favorable conditions for new particle formation and growth. NPF event frequency has been shown to be affected by at least solar radiation, $\mathrm{SO}_{2}$ concentration, vapor and particle sinks, and air mass origins (Nieminen et al., 2015; Kerminen et al., 2018). The effects of these factors are discussed in the following paragraphs in order to explain the observed NPF frequency in Hada Al Sham.

The connection between solar radiation and NPF events is related to atmospheric photochemistry: the production of sulfuric acid, which is regarded as the driving compound of atmospheric new particle formation in most environments (Weber et al., 1997; Birmili et al., 2003; Kuang et al., 2008; Paasonen et al., 2010; Yao et al., 2018), occurs mainly via oxidation of $\mathrm{SO}_{2}$ by $\mathrm{OH}$, and the concentration of $\mathrm{OH}$ is dependent on the intensity of solar radiation. Baranizadeh et al. (2014) and Dada et al. (2017) studied the effect of cloudiness on the NPF frequency at the SMEAR II station in Hyytiälä, Finland, and showed that the NPF frequency increased from $\sim 0 \%$ to over $50 \%$ with decreasing cloudiness. During some months, the NPF frequency on clear-sky days reached over $70 \%$ also in Hyytiälä, which clearly demonstrates the importance of photochemistry. The exact number of clear-sky days in Hada Al Sham could not be determined as no radiation measurements were made, but in general the radiation conditions in this area (Alnaser et al., 2004) are highly favorable for the occurrence of NPF.

Solar radiation alone is, of course, not sufficient to cause NPF if no precursor vapors for the production of nucleating and condensing compounds are available. $\mathrm{SO}_{2}$, required for the production of sulfuric acid, is emitted especially from traffic and industries that process or consume fossil fuels. In Hada Al Sham, there are no significant sources of $\mathrm{SO}_{2}$ but there are plenty of sources within a $100 \mathrm{~km}$ radius of the site, which includes the large urban and industrial areas of Jeddah and Mecca. Figure 3 displays the average $\mathrm{SO}_{2}$ concentration, retrieved by satellite measurements, in the surroundings of Hada Al Sham on NPF days. Even though these concentrations represent the amount of $\mathrm{SO}_{2}$ in the whole vertical column, the values should reflect the concentrations in the boundary layer since the most significant $\mathrm{SO}_{2}$ sources are located at ground level (for reference, $1 \mathrm{DU}$ corresponds to $11 \mathrm{ppbv}$ when distributed into a $1 \mathrm{~km}$ boundary layer at $T=300 \mathrm{~K}$ and $P=1 \mathrm{~atm})$. The figure shows that the $\mathrm{SO}_{2}$ concentrations on the coastal region are very high, close to

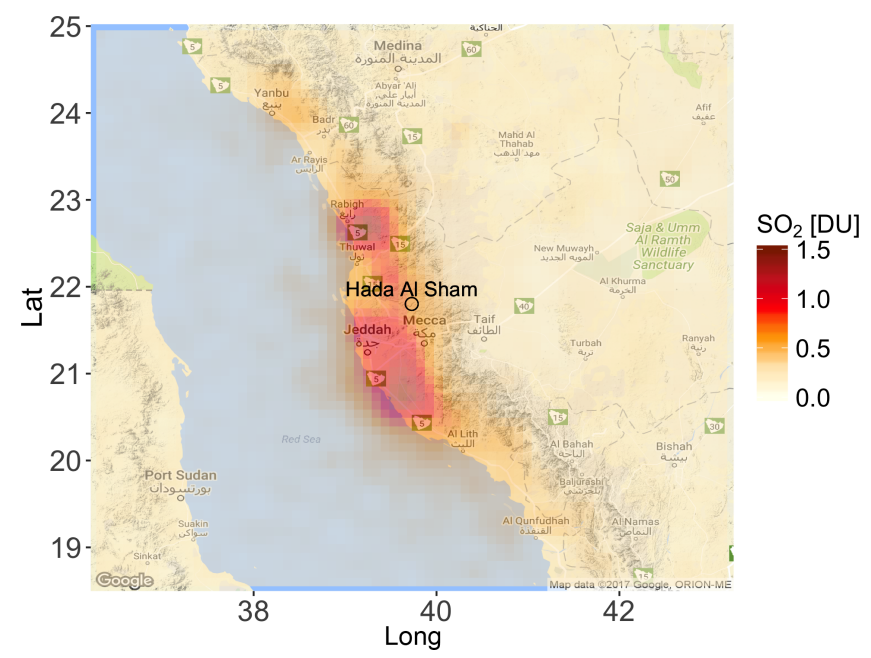

Figure 3. Average concentration of $\mathrm{SO}_{2}$ from the OMI Level $2 \mathrm{SO}_{2}$ planetary boundary layer product (Li et al., 2013) in the surroundings of Hada Al Sham during NPF days. The concentrations are shown in Dobson units $\left(1 \mathrm{DU}=2.69 \times 10^{16}\right.$ molecules $\left.\mathrm{cm}^{-2}\right)$.

those obtained from the most- $\mathrm{SO}_{2}$-polluted regions in the world (Krotkov et al., 2016). The horizontal transport of the emissions seems to be restricted by the mountains, which causes the accumulation of the concentrations on a relatively narrow area and creates a distinct boundary in the $\mathrm{SO}_{2}$ levels compared to the inland. The observed high $\mathrm{SO}_{2}$ concentrations, in combination with the radiation conditions, suggest that the production rate of sulfuric acid is high at this site.

In Fig. 4, we compare the air mass history during the mornings of NPF event and nonevent days. The shown emission sensitivities are calculated from the $24 \mathrm{~h}$ retroplumes, initiated at the time when NPF is typically taking place (10:00 LT). The comparison shows significant differences in the air mass origins between these cases. On NPF days (Fig. 4a), the air masses observed in Hada Al Sham originate mainly from a narrow strip that extends along the coast and includes the regions of significant $\mathrm{SO}_{2}$ emissions (see Fig. 3). The formation of such an air mass source region can be explained by the typically prevailing large-scale winds that blow along the Red Sea, due to tunneling caused by the steep shores. Over the coastal cities, anthropogenic emissions are introduced into the air masses and then transported to Hada Al Sham with the sea breeze that usually starts to develop already early in the morning. On nonevent days (Fig. 4b) there are no signs of the sea breeze or the typically prevailing large-scale wind. Instead, the source regions initially point towards the east, after which they spread to cover larger areas in the inland. The inland is sparsely inhabited and the sources of anthropogenic emissions are few, which can also be seen as lower average $\mathrm{SO}_{2}$ concentrations in the surroundings of Hada Al Sham on nonevent days than on NPF days (Fig. A2). The fact that all of the nonevent days are observed when the air masses are coming from the inland suggests that 
(a) NPF days (283)

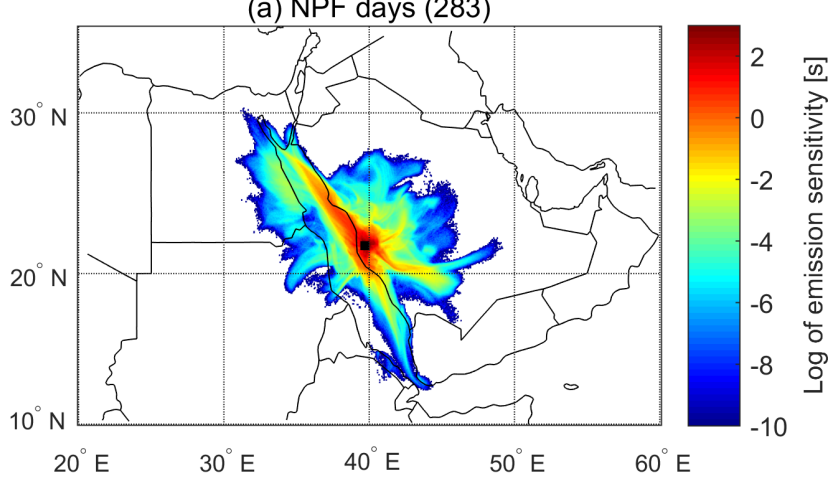

(b) Nonevent days (15)

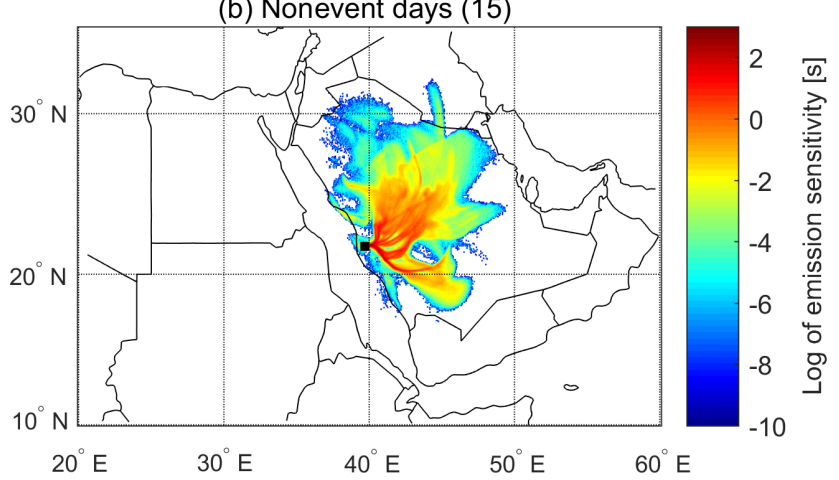

Figure 4. Average $24 \mathrm{~h}$ emission sensitivity for air masses arriving at Hada Al Sham at 10:00 LT for (a) NPF days and (b) nonevent days. The arrival time of the air masses is chosen to represent the time when new particle formation is typically taking place on NPF days (see Fig. 5).

the NPF events observed in Hada Al Sham might be related to the emissions from the coastal anthropogenic activities. In addition, the influence of marine air could be beneficial for NPF occurrence, e.g., due to lower condensation sink or some specific precursors.

The markedly different wind conditions between the NPF and nonevent days can also be seen from the local measurements at Hada Al Sham (Fig. 5a and b). On NPF days, the weak nocturnal easterly wind (land breeze) turns westerly and its speed starts to increase between 08:00 and 10:00 due to the development of the sea breeze. This shifts the air mass source regions to the coastal areas, as seen in Fig. 4a. On nonevent days, such change in the wind direction is not seen. During the night and early morning, the wind is easterly, similar to the NPF days, but, on nonevent days, the easterly wind is significantly stronger. This inhibits the development of the sea breeze circulation and the westerly wind associated with it.

The strong easterly winds on nonevent days seem to resuspend dust from the inland desert, which can be seen as the simultaneous increase in $\mathrm{PM}_{10}$ with the wind speed (Fig. 5d). Both the wind speed and the $\mathrm{PM}_{10}$ obtain their largest values around the same time when NPF typically starts (see Fig. 6). It is therefore possible that, in addition to the fewer emission sources in the inland, the NPF is inhibited by the windblown dust, which can reduce the concentrations of the clustering and condensing vapors by limiting solar radiation and by acting as a sink for reactive gases and oxidants (Hanisch and Crowley, 2003; Usher et al., 2003). The condensation sink does not, however, seem to be an inhibiting factor for NPF occurrence, as significantly larger CS values are observed on NPF days than on nonevent days (Fig. 5c). Here the presented CS values are calculated including only the particles measured by the DMPS $\left(d_{\mathrm{p}}<850 \mathrm{~nm}\right)$, but including the larger particles measured by the APS ( $d_{\mathrm{p}}$ up to $\left.10 \mu \mathrm{m}\right)$ did not have a significant effect on these results (increase in CS on nonevent days was around $10 \%$ ). Furthermore, recent studies have shown indications that mineral dust, mixed with anthropogenic emissions, could actually enhance NPF due to heterogeneous production of sulfates and hydroxyl radicals (Nie et al., 2014; Xie et al., 2015). In Hada Al Sham, the concurrence of high $\mathrm{PM}_{10}$ values and nonevent days would then mainly highlight the lack of anthropogenic emissions in the inland, although we cannot quantify the effect of $\mathrm{PM}_{10}$ on radiation.

Higher CS values during NPF days (Fig. 5c) are also reported from a high-altitude site in the Swiss Alps (Boulon et al., 2010). Here this connection is speculated to stem from the coupled appearance of NPF precursor vapors and CS due to their common lower-altitude sources. Similar situation could apply to Hada Al Sham if both the CS and the NPF precursor vapors originate mainly from the same sources. The high CS during the calm nights and early mornings of NPF days could then suggest enhanced accumulation of precursor vapors, thus facilitating the occurrence of the NPF process after sunrise.

\subsection{NPF event progression and characteristics}

Figure 6 displays the frequency histograms of the points in time describing the progression of the NPF events (see Sect. 2.2.1), together with the diurnal variation of meteorological parameters and CS. In Fig. 7, the NPF progression times are plotted for a year-long period from June 2013 to June 2014 to show their seasonal variation. NPF events are typically observed to start slightly before 09:00 (Fig. 6a). On a seasonal scale, the starting times change according to the changes in the time of sunrise (Fig. 7). This observation highlights the importance of photochemistry for the NPF, especially since none of the NPF events start before sunrise. There is, however, quite a significant day-to-day variation in the starting times, which is not explained by differences in the times of sunrise. Some of this variation can be attributed to differing growth rates between the NPF events. This is because the NPF starting times are defined here as the times when new particles are observed at the size of $7 \mathrm{~nm}$, even though the formation of new particles actually starts from 

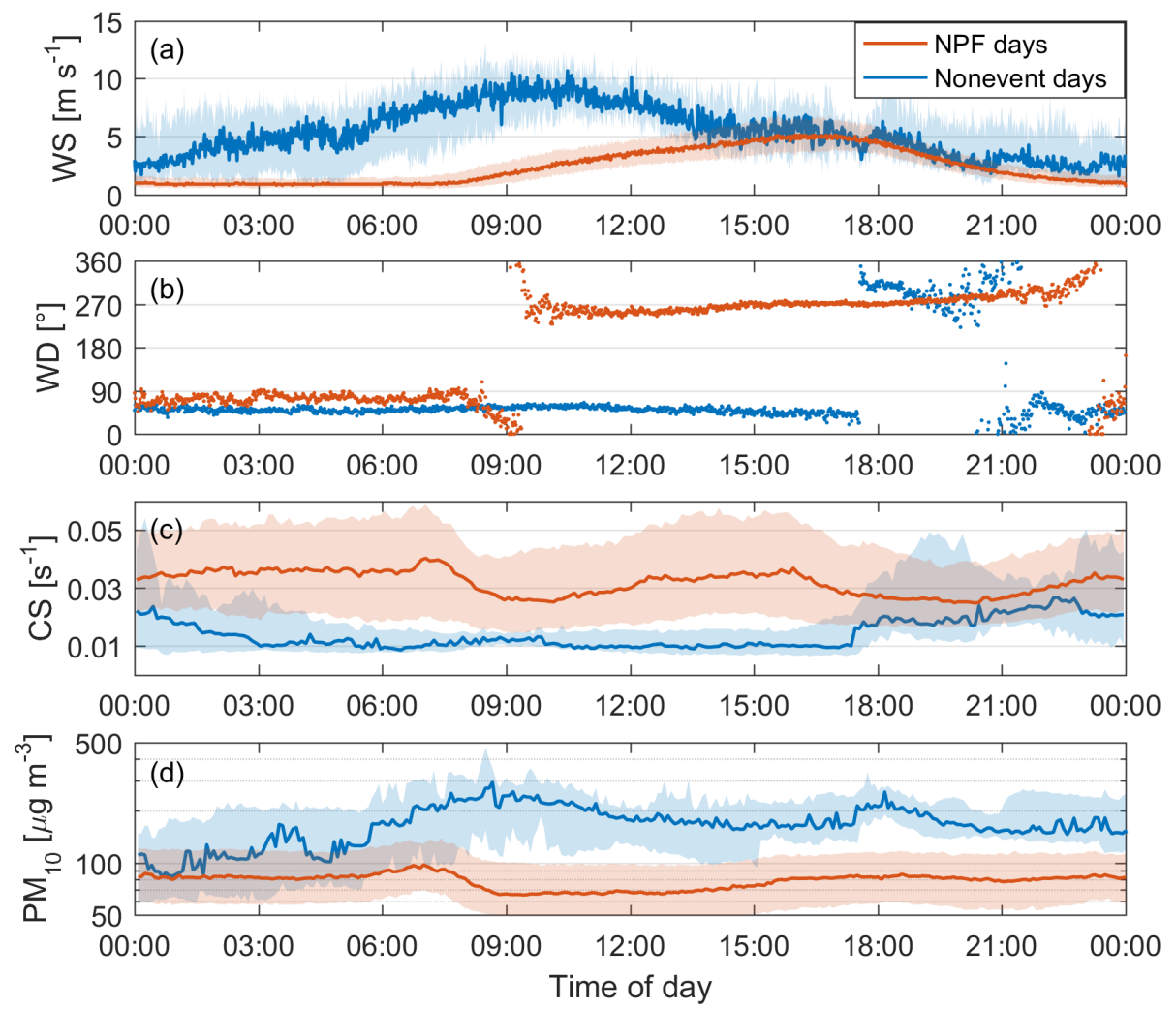

Figure 5. Diurnal variation of (a) wind speed, (b) wind direction, (c) condensation sink, and (d) mass of particles smaller than $10 \mu \mathrm{m}$ in Hada Al Sham during NPF days (red lines) and nonevent days (blue lines). The solid lines show the median values and the shaded areas represent the 25th-75th percentile range.

the molecular scale. Therefore, the time that it takes for the small particles/molecular clusters of the size $\sim 1-2 \mathrm{~nm}$ (Kulmala et al., 2013) to grow and reach the lower limit of the DMPS affects the starting times shown here. In some cases, the later NPF starting times are caused by a delayed shift in the wind direction from the inland to the coastal side of the measurement site (Fig. A3). This is in agreement with the interpretation that the NPF events observed in Hada Al Sham are related to the transport of emissions from the coastal regions. The connection between the shift in the wind direction and the onset of NPF can also be seen from the average values, as the typical onset time of the NPF events coincides with the onset of the westerly sea breeze (Fig. 6a and c). In addition to the radiation conditions and the wind direction, the starting time seems to be connected to a drop in the CS, which is likely caused by the increasing ABL height (Fig. 6a and $b$ ).

The formation of new particles lasts, on average, for about $3 \mathrm{~h}$ ending around noon. The NPF end times are possibly affected by the simultaneously increasing CS (Fig. 6a and b), which is caused by the growth of both the freshly formed and the preexisting accumulation mode particles into larger sizes. With increasing CS, NPF precursor vapors and new small particles are more likely to end up contributing to the growth of the preexisting aerosol rather than forming a new growing mode of their own. The end times could also be linked to a weakening production of condensable vapors, as discussed in the following paragraph in the context of the DMD events.

On the majority of the NPF days, the particle growth phase is followed by a DMD event. Typically, the DMD phase starts in the afternoon around 15:00, approximately $6 \mathrm{~h}$ after NPF start (Fig. 7). The onsets of the DMD events are seemingly concurrent with the maxima of the wind speed, ABL height and the temperature. This could indicate that the DMD events are caused by particle evaporation, which is triggered by the increased saturation vapor pressure at elevated temperatures and the dilution of vapor concentrations due to ABL development and wind-induced mixing. This could also explain the observed summer maximum in the DMD event frequency, since these variables, which are likely to promote particle evaporation, obtain their largest values during summer. In addition, particle evaporation might be facilitated by the decreased photochemical production of condensable vapors after the maximum intensity of solar radiation.

A vast majority $(\sim 85 \%)$ of the NPF events observed in Hada Al Sham end during the same day they started, approximately $3 \mathrm{~h}$ after DMD start or $9 \mathrm{~h}$ after NPF start (Fig. 7). Here the NPF event end times were defined as the points 

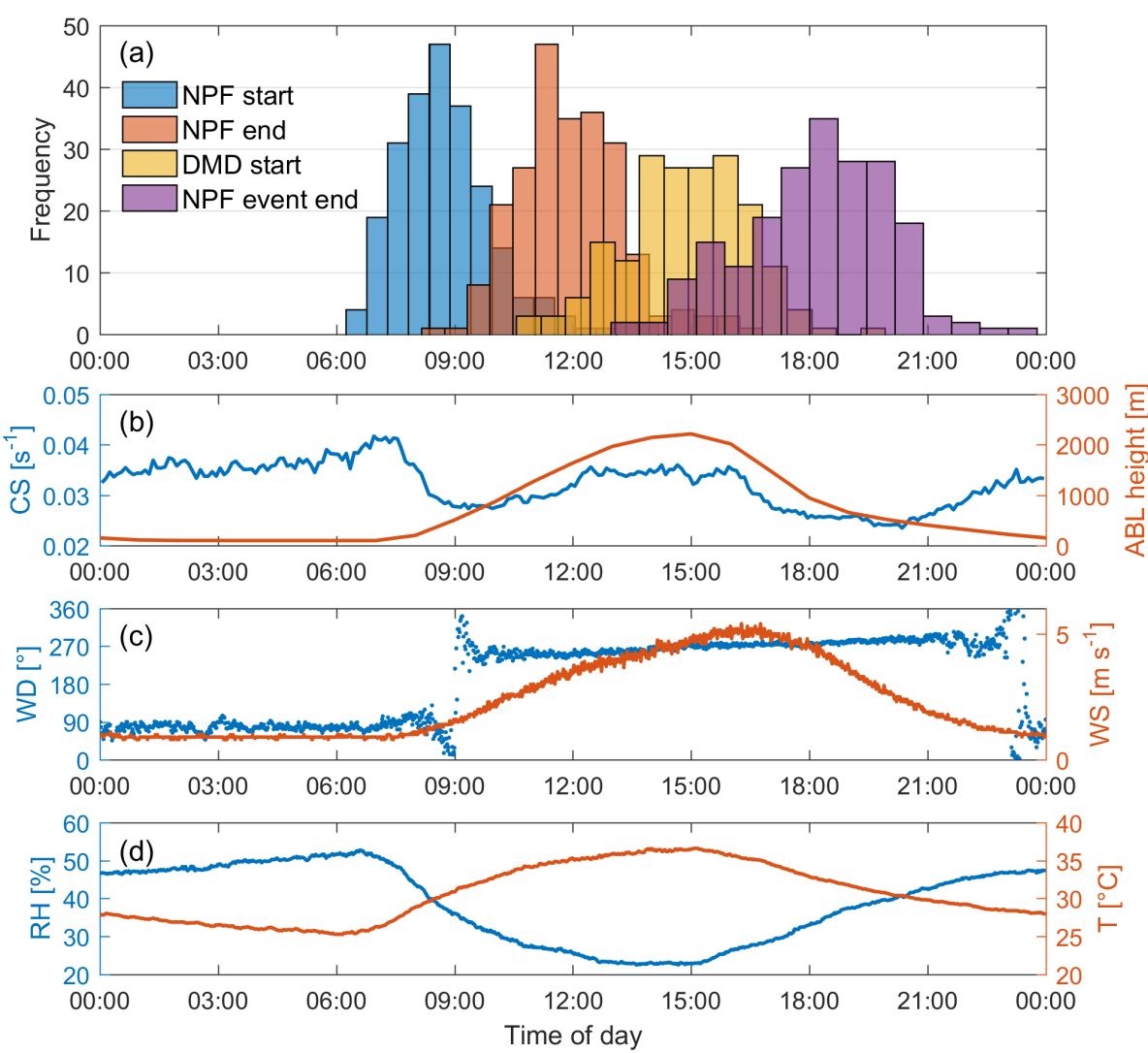

Figure 6. (a) Frequency histograms showing the temporal distribution of the different phases of the NPF events observed in Hada Al Sham (see Fig. 1) together with the median diurnal variation of (b) condensation sink and atmospheric boundary layer height, (c) wind direction and wind speed, and (d) relative humidity and temperature.

in time when the number concentrations, associated with the particle mode formed in the NPF event, drop significantly, making the mode indistinguishable from the background aerosols (see Fig. 1). Based on the observations presented earlier in this work, explaining the ending of the NPF events would be rather straightforward if they were related to the wind turning easterly at around 23:00 (Fig. 6c). However, the NPF events are typically observed to end hours before this (Fig. 6a), while the winds are still westerly. This indicates that also in the westerly direction an area where NPF is not occurring is reached. When the air masses that resided in this area during the active NPF hours (NPF start-NPF end) are transported to the measurement site, the particle mode related to NPF is no longer seen. An order-of-magnitude estimate for the westerly extent of the NPF area can be obtained by multiplying the average duration of the NPF events by the average wind speed: $10 \mathrm{~h} \times 10 \mathrm{~km} \mathrm{~h}^{-1}=100 \mathrm{~km}$. This is comparable with the distance from Hada $\mathrm{Al} \mathrm{Sham} \mathrm{to} \mathrm{the}$ coast of the Red Sea where the concentration of $\mathrm{SO}_{2}$ drops rapidly (Fig. 3). Therefore, it seems that no NPF is happening outside the region of strong contribution from anthropogenic emissions. It is reasonable to assume that there is no discrete boundary between the regions where NPF is and is not occurring. Instead, when moving away from the region of high emissions, particle formation and growth rates can be expected to decrease gradually due to the decrease in the concentrations of participating vapors. This provides another possible explanation, in addition to particle evaporation, for the observed DMD events: when the particles formed in less favorable conditions are transported to the measurement site, it is possible that they would have grown less than the previously observed particles. Continuous observations of particles that have grown less and less can produce a DMD event without particle evaporation or other shrinkage (Kivekäs et al., 2016). The cause of the DMD events observed in Hada Al Sham is further investigated in a future study.

\subsection{Particle formation and growth rates and their dependence on environmental conditions}

Figure 8 shows the seasonal variation of the particle formation rates $\left(J_{7 \mathrm{~nm}}\right)$ and growth rates $\left(\mathrm{GR}_{7-12 \mathrm{~nm}}\right)$ determined for the NPF events observed in Hada Al Sham. The formation rates (Fig. 8a) vary mostly between 1 and $50 \mathrm{~cm}^{-3} \mathrm{~s}^{-1}$, having an annual median (determined as the median of all observations) of $8.7 \mathrm{~cm}^{-3} \mathrm{~s}^{-1}$. The variation in the growth rates (Fig. 8b) is slightly smaller with the values ranging mainly 


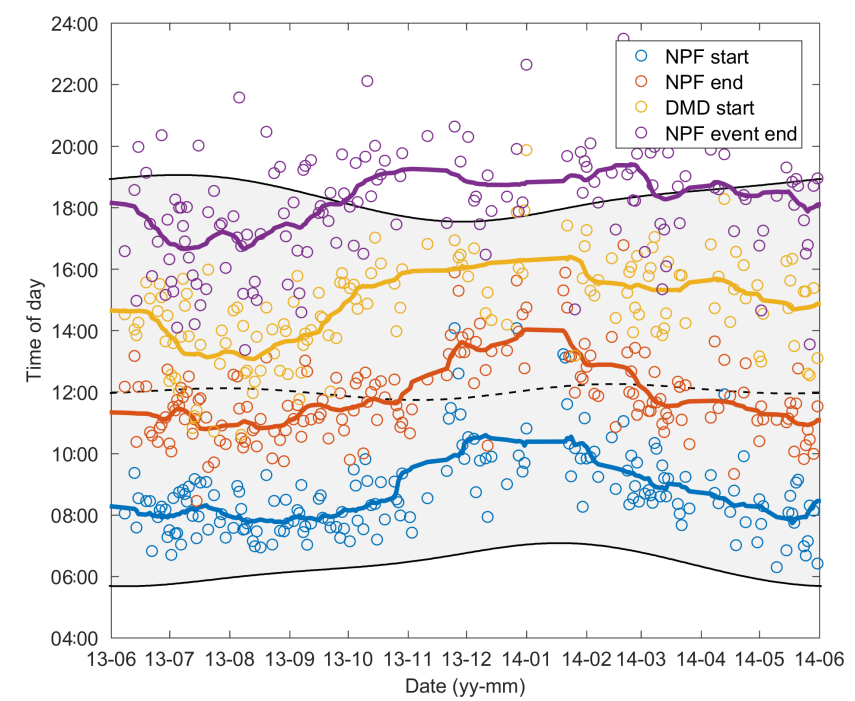

Figure 7. Seasonal variation of the different phases of the NPF events observed in Hada Al Sham. The colored lines show the 20point moving average for each of the different phases. The solid black lines show the times of sunrise and sunset, while the dashed black line shows the time of maximum solar radiation calculated based on the latitude of the measurement site.

from 2 to $20 \mathrm{~nm} \mathrm{~h}^{-1}$ and having a median of $7.4 \mathrm{~nm} \mathrm{~h}^{-1}$. The variation of these values is similar to the observations from several locations around the world (Kulmala et al., 2004), but the median values are very much in the high end of observations (Nieminen et al., 2018; Kerminen et al., 2018). Nieminen et al. (2018) reported, in their global study, the highest annual average particle formation rate from Beijing $\left(J_{10 \mathrm{~nm}} \sim 7 \mathrm{~cm}^{-3} \mathrm{~s}^{-1}\right)$ and found an overall increasing trend of formation rates with increasing degree of anthropogenic influence.

Both the formation and growth rates show a similar seasonal cycle, with the largest values during the summer and early autumn (Fig. 8a, b). For the growth rates, a summer maximum is often observed also globally, while the formation rates peak in most locations during spring (Nieminen et al., 2018). The different seasonal cycles of $J$ and GR at these sites could result from different species controlling the initial formation and further growth of the particles. In many places, the summer maximum in growth rates might be related to increased photochemical activity and increased emissions of biogenic VOCs as a function of temperature (Yli-Juuti et al., 2011), while the formation of particles could be more dependent on anthropogenic emissions (Nieminen et al., 2014). Conversely, the similar cycles of both $J$ and GR in Hada Al Sham could then suggest that here the precursor sources of particle-forming and particle-growing vapors are similar. Since the emissions from biogenic sources are expected to be minor, due to the lack of vegetation in the area, these sources are likely to be anthropogenic. In Fig. 8a, we show the monthly crude oil consumption in Saudi Arabia which seems to peak around the same time as $J$ and GR. Thus the increased emissions from energy production, resulting from the growing need for air conditioning during summer, could possibly explain the observed seasonality in $J$ and GR, although increased solar radiation is also likely to play a role.

In Fig. 8, the formation and growth rates are presented separately for the DMD and non-DMD NPF events. The comparison between these two cases is difficult due to the small number and uneven distribution of the non-DMD events. Regardless, during November-January, when the number of non-DMD events is especially large, the growth rates on non-DMD days are quite consistently lower than those on the DMD days (Fig. 8b). This would imply that the conditions between these cases are different already in the early stages of the NPF events, even though the DMD phase does not occur until hours later. The difference in the formation rates (Fig. 8a) is, however, less pronounced. One possible explanation for this could be higher concentrations of some semi/intermediate-volatility compounds on DMD days that would not participate in the initial particle formation, but would gain effectiveness with increasing particle size, due to decreasing Kelvin effect.

In Fig. 9, the formation rates are presented as a function of the relevant meteorological variables (a-d), $\mathrm{PM}_{10}$ (e) and CS (f) (see Fig. A4 for growth rates). Despite the rather pronounced seasonal variation in the formation rates (Fig. 8a), no correlation is found between the event-time (from NPF start to NPF end) temperature and $J$, when all data are considered (Fig. 9a). This is likely due to the temperature peaking already in July, while the formation rate peaks later in August. Interestingly, a strong negative correlation between $J$ and $T\left(r=-0.62, p=3 \times 10^{-5}\right)$ is observed when considering only the summer months (MJJA). This might reflect the negative effect of increasing vapor volatility on particle formation.

Figure $9 \mathrm{~b}$ shows that the formation rate increases with increasing relative humidity ( $\mathrm{RH})$. This is the expected relationship between these two variables (Almeida et al., 2013; Duplissy et al., 2016; Kürten et al., 2016), as water vapor is known to participate in the cluster formation with sulfuric acid. However, in ambient measurements such a correlation could be caused by processes that are not necessarily related to the RH effect itself. For example, here the higher RH could be related to the coastal origin of the air masses and simultaneously to higher anthropogenic emissions from the coastal sector. To examine this, the correlation was calculated separately for winds coming from the $\mathrm{S}-\mathrm{W}$ sector, where the $\mathrm{SO}_{2}$ distribution seems most uniform (Fig. 3), but a similar relationship to the case with all data was found. Furthermore, the RH relationship does not seem to be related to the seasonal variation, as both high and low RH values are observed throughout the year.

Higher formation rates seem to be favored by low wind speed and low ABL height (Fig. 9c and d). During low ABL conditions, the near-surface anthropogenic emissions 

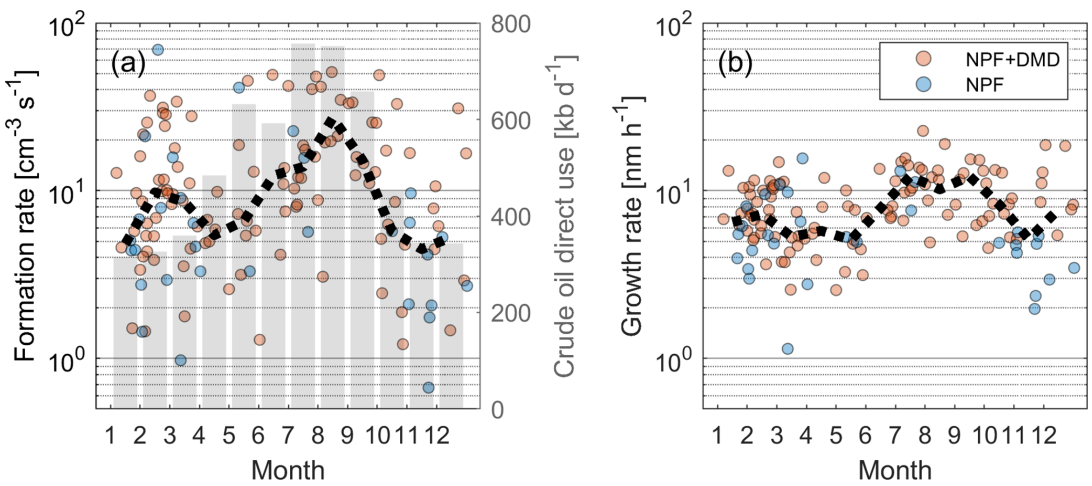

Figure 8. (a) Formation rates $\left(J_{7} \mathrm{~nm}\right)$ and (b) growth rates $\left(\mathrm{GR}_{7-12 \mathrm{~nm}}\right)$ for the NPF events observed in Hada Al Sham, separately for DMD days (red circles) and non-DMD days (blue circles). The dashed black line represents the monthly medians. The monthly crude oil direct use (https://www.jodidata.org, last access: 29 July 2019) in panel (a) (grey bars, right $Y$ axis) is calculated as the weighted average of the monthly data from the years 2013-2015. The weighing is based on the number of $J$ values from each year and month.
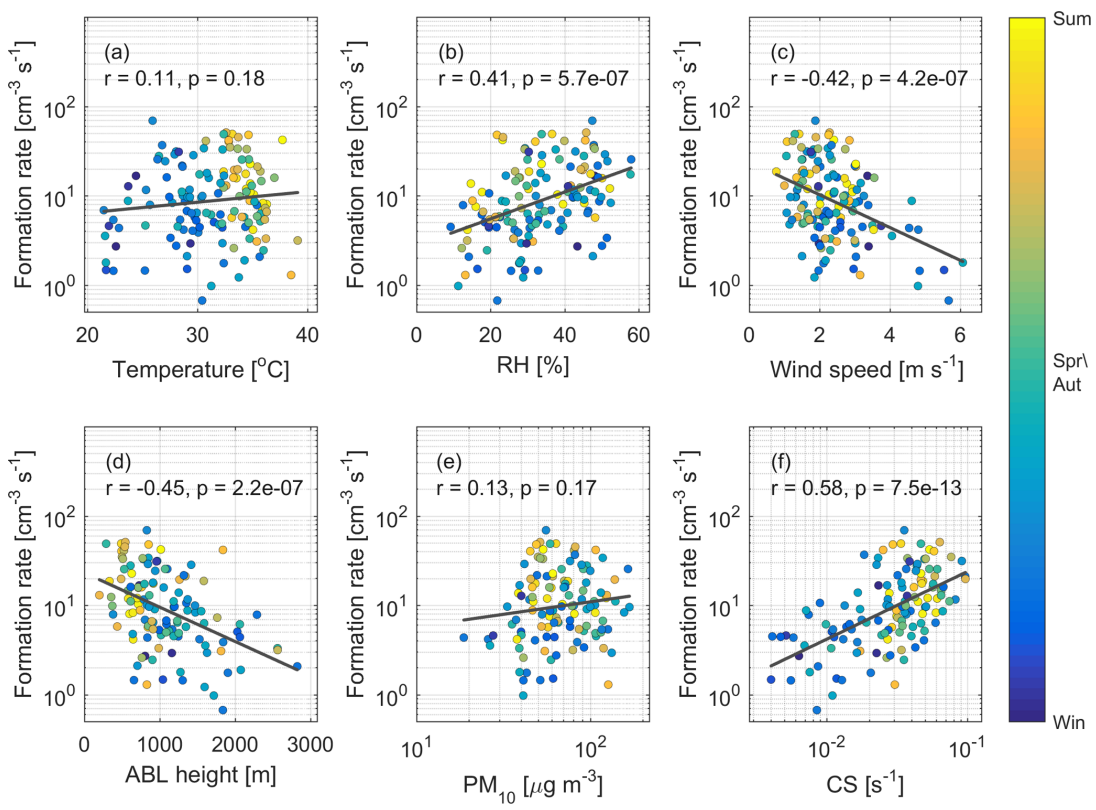

Figure 9. Particle formation rate $\left(J_{7 \mathrm{~nm}}\right)$ as a function of (a) temperature, (b) relative humidity, (c) wind speed, (d) atmospheric boundary layer height, (e) $\mathrm{PM}_{10}$ and (f) the condensation sink. The black lines show the least squares fits to the $\log -\operatorname{linear}(\mathbf{a}, \mathbf{b}, \mathbf{c}, \mathbf{d})$ or $\log -\log (\mathbf{e}$ and f) data, and the $r$ and $p$ values denote the Pearson correlation coefficients and their significance levels, respectively. The values on the horizontal axis are event-time averages (from NPF start to NPF end; see Fig. 1). In the case of the CS, the averaging was done for $1 \mathrm{~h}$ before the NPF start to make sure that the correlation is not influenced by the particles formed in the NPF event itself. The data are colored according to the season, so that summertime is represented by yellow and wintertime by blue colors.

are distributed into a smaller volume, which could then lead to higher vapor concentrations and particle formation rates. Analogously, the accumulation of emissions, per unit volume of air, from a spatially limited emission source area is increased during low wind speed conditions. Interestingly, the lowest event-time ABL heights are observed during the summer months (Fig. 9d), meaning that, in addition to the summer NPF events occurring earlier in the absolute sense (see Fig. 7), they also take place earlier with respect to the boundary layer development. This observation could be caused by the higher emissions during summer (see Fig. 8a), since if the concentrations of NPF precursors are higher, the onset of NPF events is likely to be more sensitive to an increase in solar radiation. We note that the $\mathrm{RH}$ dependence might also arise partly from higher RH in low ABL and wind speed conditions. However, since the correlation of $\mathrm{RH}$ and either ABL height or wind speed is weaker than that between $\mathrm{RH}$ and the formation rate, we expect this connection to be of secondary importance. 
In the end of Sect. 3.1, we discussed briefly the possible interactions between NPF and mineral dust, which is likely the major component of $\mathrm{PM}_{10}$ in Hada Al Sham. We stated that mineral dust can possibly either weaken (increasing sink and decreased solar radiation) or enhance (increasing production of hydroxyl radicals and sulfates via heterogeneous reactions) the NPF events. The enhancing effect has been observed specifically in situations where mineral dust is mixed with anthropogenic pollution (Nie et al., 2014), which could correspond to the situation in Hada Al Sham. Despite this, no clear correlation was found between $\mathrm{PM}_{10}$ and the formation (or growth) rates (Figs. 9e and A4e). It should be noted that in the case presented by Nie et al. (2014) the timescale of the process is significantly longer, as both the sources of the dust and the anthropogenic emissions are located further away from the measurement site. This allows for a longer interaction time between the dust and the emissions, which might be crucial for the enhancing effect to occur.

Out of the included variables, the strongest correlation is found between particle formation rates and CS (Fig. 9f). This positive correlation is quite interesting, since the concentrations of vapors participating in NPF are expected to decrease with increasing CS due to their faster loss rate. However, this is generally valid only if the sources of the CS and the condensing vapors are independent from one another. Here, this is likely not the case, but instead the increasing CS presumably represents increasing contribution from the (primary) anthropogenic emissions and is therefore simultaneously linked to higher concentrations of NPF precursor vapors. This is supported by the observation that both the CS and $\mathrm{SO}_{2}$ concentration are higher during the NPF days than nonevent days (Figs. 5c and A2).

Figure A4 shows the particle growth rates as a function of the same variables as the particle formation rates in Fig. 9. Overall, the correlations are qualitatively similar but weaker in the case of GRs. Similarly to the formation rates, the strongest correlation is found with the CS $(r=0.37, p=$ $2.2 \times 10^{-5}$ ). The most notable difference is that, in the case of GRs, a weak positive correlation with temperature $(r=0.19$, $p=0.025)$ is observed.

\section{Summary and conclusions}

The analysis of the aerosol number size distribution measurements showed that NPF events are a highly frequent phenomenon in Hada Al Sham, with the fraction of NPF days accounting for $73 \%$ of all the classified days. The high NPF frequency is likely explained by the high production of NPF precursor vapors, especially sulfuric acid, in the transported emission plumes from the coastal cities and industrial areas during the typically prevailing cloud-free and high-solarintensity conditions. The fraction of nonevent days was only $4 \%$, and these days were shown to be linked to strong easterly winds that block the development of the sea breeze, which typically brings the polluted air masses to Hada Al Sham.

Most of the NPF events in Hada Al Sham displayed an unusual progression, where the diameter of the particle mode related to the NPF event started to decrease after the growth phase. Similar DMD events have been observed in other measurement sites as well, but in Hada Al Sham the frequency of these events was found to be exceptionally high ( $76 \%$ of all NPF days). The DMD events were more frequent during the summer, and the average onset time of the DMD events was during the afternoon, approximately $6 \mathrm{~h}$ after NPF start.

The median particle formation and growth rates associated with the NPF events were $8.7 \mathrm{~cm}^{-3} \mathrm{~s}^{-1}\left(J_{7 \mathrm{~nm}}\right)$ and $7.4 \mathrm{~nm} \mathrm{~h}^{-1}\left(\mathrm{GR}_{7-12 \mathrm{~nm}}\right)$, respectively. These values correspond to those typically obtained from polluted urban measurement sites. Both the formation and growth rates showed the highest values during summer and autumn months, presumably due to the increased emissions from energy production and the effect of stronger solar radiation on the rate of photochemical reactions. The formation rates were found to obtain higher values in calm conditions where both the wind speed and the ABL height were low and the relative humidity was high. Under such circumstances, anthropogenic emissions are likely to spread and accumulate throughout the coastal zone, including Hada Al Sham. Both the formation and growth rates obtained higher values in conditions of high CS, which is likely associated with the common anthropogenic sources of NPF precursor vapors and the large primary particles that control the CS.

Overall, the findings of this study highlight the importance of anthropogenic emissions and photochemistry for NPF. Due to the transportation of emissions from urban and industrial areas, NPF events were found to be very frequent in Hada Al Sham, located tens of kilometers away from the major sources. The frequency and strength of NPF observed here implies that NPF events might contribute significantly to the budget of both ultrafine and $\mathrm{CCN}$ particles, making their health and climate effects relevant topics for further studies in this region. The local conditions at Hada Al Sham, with high levels of regional anthropogenic emissions but presumably low concentrations of biogenic vapors, also allow us to research anthropogenic NPF events in detail. However, further experiments with a broader spectrum of instruments are required for determining the vapors responsible for new particle formation and growth, as well as the underlying reasons for the occurrence of the DMD events.

Data availability. Data used in this study are available from the corresponding author upon request (simo.hakala@helsinki.fi). 


\section{Appendix A}
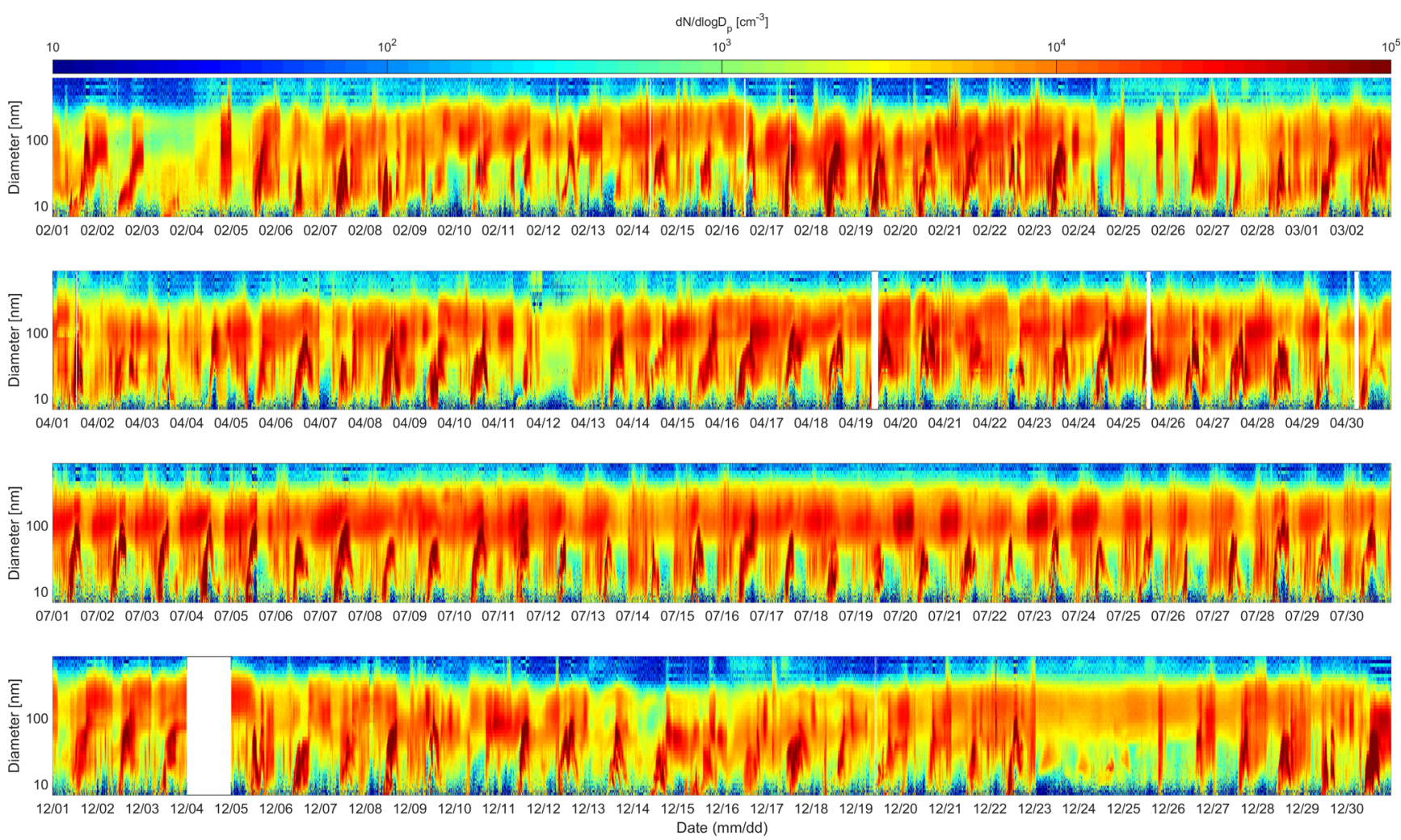

Figure A1. Time series of particle number size distributions during February 2013, April 2014, July 2013 and December 2013 illustrating the high frequency and typical characteristics of NPF, as well as periods of nonevent and undefined days, e.g., during 23-27 December 2013. The shown time series were selected so that they would cover different seasons with continuous data availability.

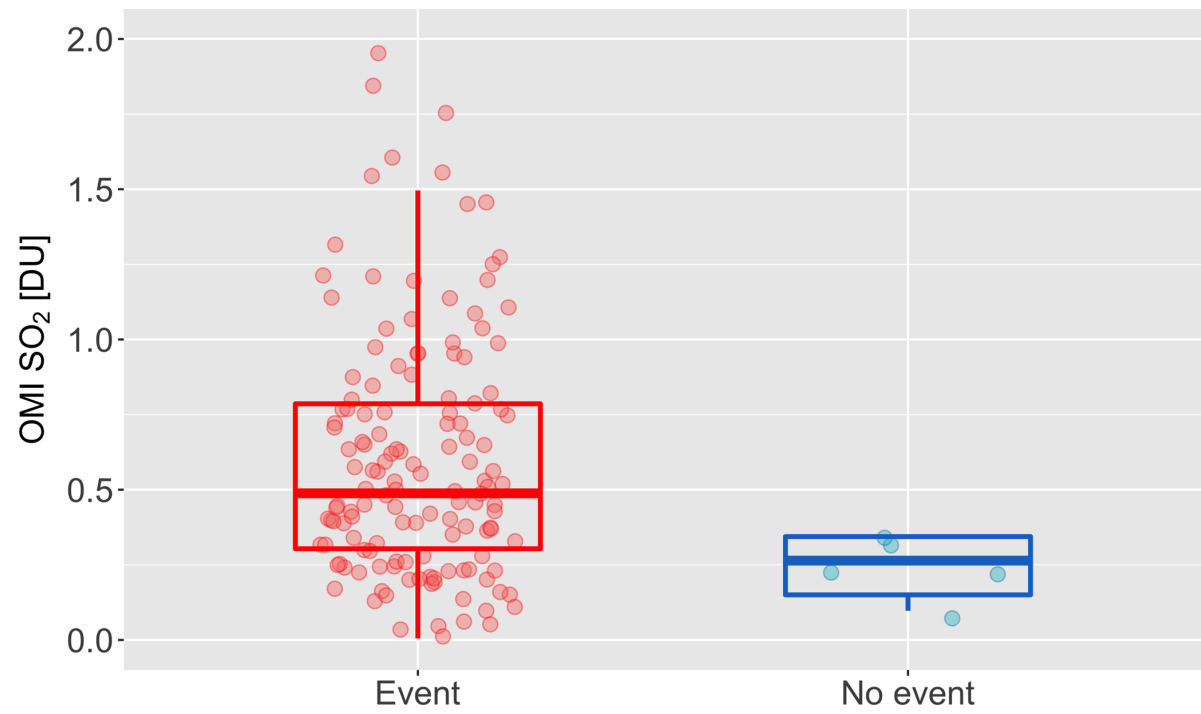

Figure A2. The average $\mathrm{SO}_{2}$ concentration within the radius of $50 \mathrm{~km}$ from Hada Al Sham during NPF days and nonevent days from the OMI Level $2 \mathrm{SO}_{2}$ planetary boundary layer product (Li et al., 2013). The concentrations are shown in Dobson units $(1 \mathrm{DU}=2.69 \times$ $10^{16}$ molecules $\mathrm{cm}^{-2}$ ). 


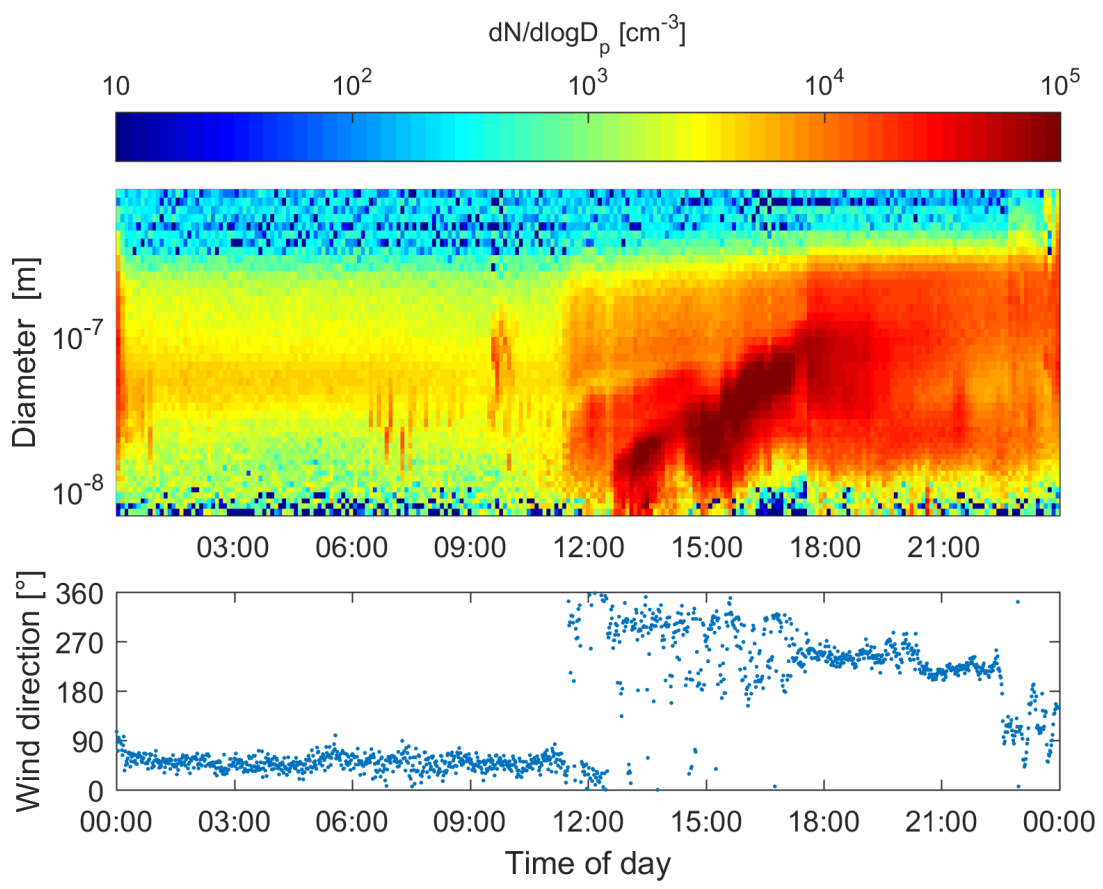

Figure A3. An example illustrating a case where the late starting time of an NPF event is related to a delayed shift in the wind direction in Hada Al Sham, 5 February 2013.
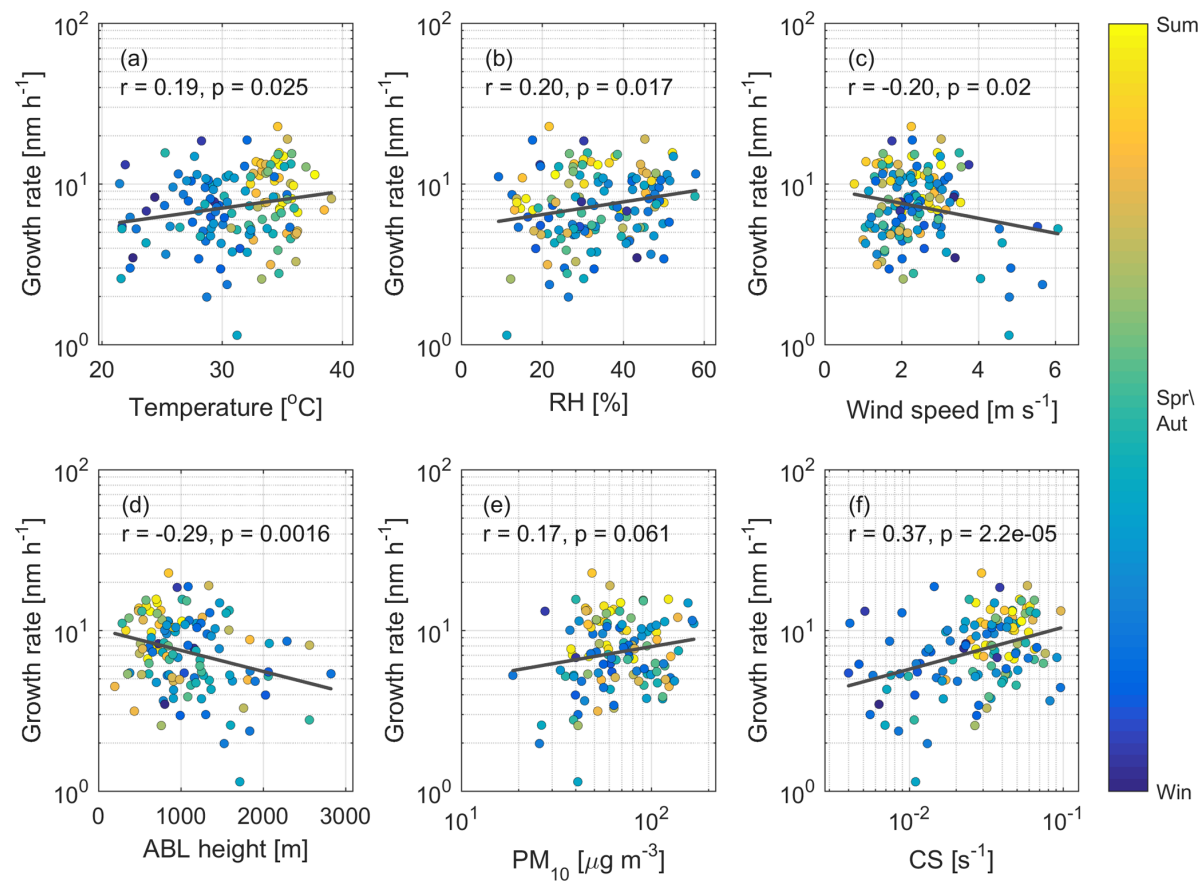

Figure A4. Particle growth rate $\left(\mathrm{GR}_{7-12 \mathrm{~nm}}\right)$ as a function of (a) temperature, (b) relative humidity, (c) wind speed, (d) atmospheric boundary layer height, (e) $\mathrm{PM}_{10}$ and (f) the condensation sink. The black lines show the least squares fits to the log-linear (a, b, c, d) or log-log (e and f) data, and the $r$ and $p$ values denote the Pearson correlation coefficients and their significance levels, respectively. The values on the horizontal axis are event-time averages (from NPF start to NPF end; see Fig. 1). In the case of the CS, the averaging was done for $1 \mathrm{~h}$ before the NPF start to make sure that the correlation is not influenced by the particles formed in the NPF event itself. The data are colored according to the season, so that summertime is represented by yellow and wintertime by blue colors. 
Author contributions. MIK, HAJ, MAA, HL, APH and TH coordinated the measurement program and carried it out with $\mathrm{KN}, \mathrm{LD}$, ASA, IIS and FMA. ASA, IIS and FMA also provided resources and data curation. VV provided the essential means for calculating and analyzing the air mass trajectories. AMS produced the figures related to the $\mathrm{OMI} \mathrm{SO}_{2}$ data. $\mathrm{SH}$ and $\mathrm{PP}$ performed the data analysis, while VV, VMK, JK and MK contributed to the interpretation of the results. $\mathrm{SH}$ wrote the manuscript with contributions from all coauthors.

Competing interests. The authors declare that they have no conflict of interest.

Acknowledgements. We would like to thank the editor, Fangqun Yu, and the two anonymous referees for their insightful comments that helped us improve the manuscript.

Financial support. This research was funded by the Deanship of Scientific Research, King Abdulaziz University (grant no. I-12230); the Academy of Finland (grant nos. 307331 and 316114); and the European Commission (grant no. 742206).

Open access funding provided by Helsinki University Library.

Review statement. This paper was edited by Fangqun Yu and reviewed by two anonymous referees.

\section{References}

Almeida, J., Schobesberger, S., Kurten, A., Ortega, I. K., Kupiainen-Maatta, O., Praplan, A. P., Adamov, A., Amorim, A., Bianchi, F., Breitenlechner, M., David, A., Dommen, J., Donahue, N. M., Downard, A., Dunne, E., Duplissy, J., Ehrhart, S., Flagan, R. C., Franchin, A., Guida, R., Hakala, J., Hansel, A., Heinritzi, M., Henschel, H., Jokinen, T., Junninen, H., Kajos, M., Kangasluoma, J., Keskinen, H., Kupc, A., Kurten, T., Kvashin, A. N., Laaksonen, A., Lehtipalo, K., Leiminger, M., Leppa, J., Loukonen, V., Makhmutov, V., Mathot, S., McGrath, M. J., Nieminen, T., Olenius, T., Onnela, A., Petaja, T., Riccobono, F., Riipinen, I., Rissanen, M., Rondo, L., Ruuskanen, T., Santos, F. D., Sarnela, N., Schallhart, S., Schnitzhofer, R., Seinfeld, J. H., Simon, M., Sipila, M., Stozhkov, Y., Stratmann, F., Tome, A., Trostl, J., Tsagkogeorgas, G., Vaattovaara, P., Viisanen, Y., Virtanen, A., Vrtala, A., Wagner, P. E., Weingartner, E., Wex, H., Williamson, C., Wimmer, D., Ye, P. L., Yli-Juuti, T., Carslaw, K. S., Kulmala, M., Curtius, J., Baltensperger, U., Worsnop, D. R., Vehkamaki, H., and Kirkby, J.: Molecular understanding of sulphuric acid-amine particle nucleation in the atmosphere, Nature, 502, 359-363, https://doi.org/10.1038/nature12663, 2013.

Alnaser, W. E., Eliagoubi, B., Al-Kalak, A., Trabelsi, H., AlMaalej, M., El-Sayed, H. M., and Alloush, M.: First solar radiation atlas for the Arab world, Renew. Energ., 29, 1085-1107, https://doi.org/10.1016/j.renene.2003.10.007, 2004.
Alonso-Blanco, E., Gómez-Moreno, F. J., Núñez, L., Pujadas, M., Cusack, M., and Artíñano, B.: Aerosol particle shrinkage event phenomenology in a South European suburban area during 2009-2015, Atmos. Environ., 160, 154-164, https://doi.org/10.1016/j.atmosenv.2017.04.013, 2017.

Backman, J., Rizzo, L. V., Hakala, J., Nieminen, T., Manninen, H. E., Morais, F., Aalto, P. P., Siivola, E., Carbone, S., Hillamo, R., Artaxo, P., Virkkula, A., Petäjä, T., and Kulmala, M.: On the diurnal cycle of urban aerosols, black carbon and the occurrence of new particle formation events in springtime São Paulo, Brazil, Atmos. Chem. Phys., 12, 11733-11751, https://doi.org/10.5194/acp-12-11733-2012, 2012.

Baranizadeh, E., Arola, A., Hamed, A., Nieminen, T., Mikkonen, S., Virtanen, A., Kulmala, M., Lehtinen, K., and Laaksonen, A. The effect of cloudiness on new-particle formation: investigation of radiation levels, Boreal Environ. Res., 19, 343-354, 2014.

Birmili, W., Berresheim, H., Plass-Dülmer, C., Elste, T., Gilge, S., Wiedensohler, A., and Uhrner, U.: The Hohenpeissenberg aerosol formation experiment (HAFEX): a long-term study including size-resolved aerosol, $\mathrm{H} 2 \mathrm{SO} 4, \mathrm{OH}$, and monoterpenes measurements, Atmos. Chem. Phys., 3, 361-376, https://doi.org/10.5194/acp-3-361-2003, 2003.

Boulon, J., Sellegri, K., Venzac, H., Picard, D., Weingartner, E., Wehrle, G., Collaud Coen, M., Bütikofer, R., Flückiger, E., Baltensperger, U., and Laj, P.: New particle formation and ultrafine charged aerosol climatology at a high altitude site in the Alps (Jungfraujoch, $3580 \mathrm{~m}$ a.s.l., Switzerland), Atmos. Chem. Phys., 10, 9333-9349, https://doi.org/10.5194/acp-109333-2010, 2010.

Buenrostro Mazon, S., Riipinen, I., Schultz, D. M., Valtanen, M., Dal Maso, M., Sogacheva, L., Junninen, H., Nieminen, T., Kerminen, V.-M., and Kulmala, M.: Classifying previously undefined days from eleven years of aerosol-particle-size distribution data from the SMEAR II station, Hyytiälä, Finland, Atmos. Chem. Phys., 9, 667-676, https://doi.org/10.5194/acp-9667-2009, 2009

Cusack, M., Alastuey, A., and Querol, X.: Case studies of new particle formation and evaporation processes in the western Mediterranean regional background, Atmos. Environ., 81, 651659, https://doi.org/10.1016/j.atmosenv.2013.09.025, 2013.

Dada, L., Paasonen, P., Nieminen, T., Buenrostro Mazon, S., Kontkanen, J., Peräkylä, O., Lehtipalo, K., Hussein, T., Petäjä, T., Kerminen, V.-M., Bäck, J., and Kulmala, M.: Long-term analysis of clear-sky new particle formation events and nonevents in Hyytiälä, Atmos. Chem. Phys., 17, 6227-6241, https://doi.org/10.5194/acp-17-6227-2017, 2017.

Dal Maso, M., Kulmala, M., Riipinen, I., Wagner, R., Hussein, T., Aalto, P. P., and Lehtinen, K. E. J.: Formation and growth of fresh atmospheric aerosols: eight years of aerosol size distribution data from SMEAR II, Hyytiälä, Finland, Boreal Environ. Res., 10, 323-336, 2005.

Dall'Osto, M., Beddows, D. C. S., Asmi, A., Poulain, L., Hao, L., Freney, E., Allan, J. D., Canagaratna, M., Crippa, M., Bianchi, F., de Leeuw, G., Eriksson, A., Swietlicki, E., Hansson, H. C., Henzing, J. S., Granier, C., Zemankova, K., Laj, P., Onasch, T., Prevot, A., Putaud, J. P., Sellegri, K., Vidal, M., Virtanen, A., Simo, R., Worsnop, D., O'Dowd, C., Kulmala, M., and Harrison, R. M.: Novel insights on new particle formation derived 
from a pan-european observing system, Sci. Rep.-UK, 8, 1482, https://doi.org/10.1038/s41598-017-17343-9, 2018.

Duplissy, J., Merikanto, J., Franchin, A., Tsagkogeorgas, G., Kangasluoma, J., Wimmer, D., Vuollekoski, H., Schobesberger, S., Lehtipalo, K., Flagan, R. C., Brus, D., Donahue, N. M., Vehkamaki, H., Almeida, J., Amorim, A., Barmet, P., Bianchi, F., Breitenlechner, M., Dunne, E. M., Guida, R., Henschel, H., Junninen, H., Kirkby, J., Kurten, A., Kupc, A., Maattanen, A., Makhmutov, V., Mathot, S., Nieminen, T., Onnela, A., Praplan, A. P., Riccobono, F., Rondo, L., Steiner, G., Tome, A., Walther, H., Baltensperger, U., Carslaw, K. S., Dommen, J., Hansel, A., Petaja, T., Sipila, M., Stratmann, F., Vrtala, A., Wagner, P. E., Worsnop, D. R., Curtius, J., and Kulmala, M.: Effect of ions on sulfuric acid-water binary particle formation: 2 . Experimental data and comparison with QC-normalized classical nucleation theory, J. Geophys. Res.-Atmos., 121, 1752-1775, https://doi.org/10.1002/2015jd023539, 2016.

Ehrhart, S., Ickes, L., Almeida, J., Amorim, A., Barmet, P., Bianchi, F., Dommen, J., Dunne, E. M., Duplissy, J., Franchin, A., Kangasluoma, J., Kirkby, J., Kurten, A., Kupc, A., Lehtipalo, K., Nieminen, T., Riccobono, F., Rondo, L., Schobesberger, S., Steiner, G., Tome, A., Wimmer, D., Baltensperger, U., Wagner, P. E., and Curtius, J.: Comparison of the SAWNUC model with CLOUD measurements of sulphuric acidwater nucleation, J. Geophys. Res.-Atmos., 121, 12401-12414, https://doi.org/10.1002/2015jd023723, 2016.

Fuchs, N. A.: The mechanics of aerosols, Rev. and enl. edn., Pergamon Press, Oxford, 408 pp., 1964.

Fuchs, N. A. and Sutugin, A. G.: Highly dispersed aerosols, Ann Arbour Science Publishers, Ann Arbour, London, 1970.

Gordon, H., Sengupta, K., Rap, A., Duplissy, J., Frege, C., Williamson, C., Heinritzi, M., Simon, M., Yan, C., Almeida, J., Trostl, J., Nieminen, T., Ortega, I. K., Wagner, R., Dunne, E. M., Adamov, A., Amorim, A., Bernhammer, A. K., Bianchi, F., Breitenlechner, M., Brilke, S., Chen, X. M., Craven, J. S., Dias, A., Ehrhart, S., Fischer, L., Flagan, R. C., Franchin, A., Fuchs, C., Guida, R., Hakala, J., Hoyle, C. R., Jokinen, T., Junninen, H., Kangasluoma, J., Kim, J., Kirkby, J., Krapf, M., Kurten, A., Laaksonen, A., Lehtipalo, K., Makhmutov, V., Mathot, S., Molteni, U., Monks, S. A., Onnela, A., Perakyla, O., Piel, F., Petaja, T., Praplanh, A. P., Pringle, K. J., Richards, N. A. D., Rissanen, M. P., Rondo, L., Sarnela, N., Schobesberger, S., Scott, C. E., Seinfeldo, J. H., Sharma, S., Sipila, M., Steiner, G., Stozhkov, Y., Stratmann, F., Tome, A., Virtanen, A., Vogel, A. L., Wagner, A. C., Wagner, P. E., Weingartner, E., Wimmer, D., Winkler, P. M., Ye, P. L., Zhang, X., Hansel, A., Dommen, J., Donahue, N. M., Worsnop, D. R., Baltensperger, U., Kulmala, M., Curtius, J., and Carslaw, K. S.: Reduced anthropogenic aerosol radiative forcing caused by biogenic new particle formation, P. Natl. Acad. Sci. USA, 113, 12053-12058, https://doi.org/10.1073/pnas.1602360113, 2016.

Gordon, H., Kirkby, J., Baltensperger, U., Bianchi, F., Breitenlechner, M., Curtius, J., Dias, A., Dommen, J., Donahue, N. M., Dunne, E. M., Duplissy, J., Ehrhart, S., Flagan, R. C., Frege, C., Fuchs, C., Hansel, A., Hoyle, C. R., Kulmala, M., Kurten, A., Lehtipalo, K., Makhmutov, V., Molteni, U., Rissanen, M. P., Stozkhov, Y., Trostl, J., Tsagkogeorgas, G., Wagner, R., Williamson, C., Wimmer, D., Winkler, P. M., Yan, C., and Carslaw, K. S.: Causes and importance of new particle formation in the present-day and preindustrial atmospheres, J. Geophys. Res.-Atmos., 122, 8739-8760, https://doi.org/10.1002/2017jd026844, 2017.

Hanisch, F. and Crowley, J. N.: Ozone decomposition on Saharan dust: an experimental investigation, Atmos. Chem. Phys., 3, 119130, https://doi.org/10.5194/acp-3-119-2003, 2003.

Hirsikko, A., Vakkari, V., Tiitta, P., Manninen, H. E., Gagné, S., Laakso, H., Kulmala, M., Mirme, A., Mirme, S., Mabaso, D., Beukes, J. P., and Laakso, L.: Characterisation of submicron particle number concentrations and formation events in the western Bushveld Igneous Complex, South Africa, Atmos. Chem. Phys., 12, 3951-3967, https://doi.org/10.5194/acp12-3951-2012, 2012.

Hussein, T., Dal Maso, M., Petaja, T., Koponen, I. K., Paatero, P., Aalto, P. P., Hameri, K., and Kulmala, M.: Evaluation of an automatic algorithm for fitting the particle number size distributions, Boreal Environ. Res., 10, 337-355, 2005.

Kerminen, V. M., Chen, X. M., Vakkari, V., Petaja, T., Kulmala, M., and Bianchi, F.: Atmospheric new particle formation and growth: review of field observations, Environ. Res. Lett., 13, 103003, https://doi.org/10.1088/1748-9326/aadf3c, 2018.

Kirkby, J., Curtius, J., Almeida, J., Dunne, E., Duplissy, J., Ehrhart, S., Franchin, A., Gagne, S., Ickes, L., Kurten, A., Kupc, A., Metzger, A., Riccobono, F., Rondo, L., Schobesberger, S., Tsagkogeorgas, G., Wimmer, D., Amorim, A., Bianchi, F., Breitenlechner, M., David, A., Dommen, J., Downard, A., Ehn, M., Flagan, R. C., Haider, S., Hansel, A., Hauser, D., Jud, W., Junninen, H., Kreissl, F., Kvashin, A., Laaksonen, A., Lehtipalo, K., Lima, J., Lovejoy, E. R., Makhmutov, V., Mathot, S., Mikkila, J., Minginette, P., Mogo, S., Nieminen, T., Onnela, A., Pereira, P., Petaja, T., Schnitzhofer, R., Seinfeld, J. H., Sipila, M., Stozhkov, Y., Stratmann, F., Tome, A., Vanhanen, J., Viisanen, Y., Vrtala, A., Wagner, P. E., Walther, H., Weingartner, E., Wex, H., Winkler, P. M., Carslaw, K. S., Worsnop, D. R., Baltensperger, U., and Kulmala, M.: Role of sulphuric acid, ammonia and galactic cosmic rays in atmospheric aerosol nucleation, Nature, 476, 429-477, https://doi.org/10.1038/nature10343, 2011.

Kivekäs, N., Carpman, J., Roldin, P., Leppa, J., O'Connor, E., Kristensson, A., and Asmi, E.: Coupling an aerosol box model with one-dimensional flow: a tool for understanding observations of new particle formation events, Tellus B, 68, 29706, https://doi.org/10.3402/tellusb.v68.29706, 2016.

Krotkov, N. A., McLinden, C. A., Li, C., Lamsal, L. N., Celarier, E. A., Marchenko, S. V., Swartz, W. H., Bucsela, E. J., Joiner, J., Duncan, B. N., Boersma, K. F., Veefkind, J. P., Levelt, P. F., Fioletov, V. E., Dickerson, R. R., He, H., Lu, Z., and Streets, D. G.: Aura OMI observations of regional $\mathrm{SO}_{2}$ and $\mathrm{NO}_{2}$ pollution changes from 2005 to 2015, Atmos. Chem. Phys., 16, 46054629, https://doi.org/10.5194/acp-16-4605-2016, 2016.

Kuang, C., McMurry, P. H., McCormick, A. V., and Eisele, F. L.: Dependence of nucleation rates on sulfuric acid vapor concentration in diverse atmospheric locations, J. Geophys. Res.-Atmos., 113, D10209, https://doi.org/10.1029/2007jd009253, 2008.

Kuang, C., McMurry, P. H., and McCormick, A. V.: Determination of cloud condensation nuclei production from measured new particle formation events, Geophys. Res. Lett., 36, L09822, https://doi.org/10.1029/2009gl037584, 2009.

Kulmala, M., Dal Maso, M., Makela, J. M., Pirjola, L., Vakeva, M., Aalto, P., Miikkulainen, P., Hameri, K., and O’Dowd, C. D.: 
On the formation, growth and composition of nucleation mode particles, Tellus B, 53, 479-490, https://doi.org/10.1034/j.16000889.2001.530411.x, 2001.

Kulmala, M., Vehkamaki, H., Petaja, T., Dal Maso, M., Lauri, A., Kerminen, V. M., Birmili, W., and McMurry, P. H.: Formation and growth rates of ultrafine atmospheric particles: a review of observations, J. Aerosol. Sci., 35, 143-176, https://doi.org/10.1016/j.jaerosci.2003.10.003, 2004.

Kulmala, M., Petäjä, T., Nieminen, T., Sipilä, M., Manninen, H. E., Lehtipalo, K., Dal Maso, M., Aalto, P. P., Junninen, H., Paasonen, P., Riipinen, I., Lehtinen, K. E. J., Laaksonen, A., and Kerminen, V.-M.: Measurement of the nucleation of atmospheric aerosol particles, Nat. Protocols, 7, 1651-1667, 2012.

Kulmala, M., Kontkanen, J., Junninen, H., Lehtipalo, K., Manninen, H. E., Nieminen, T., Petaja, T., Sipila, M., Schobesberger, S., Rantala, P., Franchin, A., Jokinen, T., Jarvinen, E., Aijala, M., Kangasluoma, J., Hakala, J., Aalto, P. P., Paasonen, P., Mikkila, J., Vanhanen, J., Aalto, J., Hakola, H., Makkonen, U., Ruuskanen, T., Mauldin, R. L., Duplissy, J., Vehkamaki, H., Back, J., Kortelainen, A., Riipinen, I., Kurten, T., Johnston, M. V., Smith, J. N., Ehn, M., Mentel, T. F., Lehtinen, K. E. J., Laaksonen, A., Kerminen, V. M., and Worsnop, D. R.: Direct Observations of Atmospheric Aerosol Nucleation, Science, 339, 943 946, https://doi.org/10.1126/science.1227385, 2013.

Kulmala, M., Luoma, K., Virkkula, A., Petaja, T., Paasonen, P., Kerminen, V. M., Nie, W., Qi, X. M., Shen, Y. C., Chi, X. G., and Ding, A. J.: On the mode-segregated aerosol particle number concentration load: contributions of primary and secondary particles in Hyytiala and Nanjing, Boreal Environ. Res., 21, 319-331, 2016.

Kürten, A., Jokinen, T., Simon, M., Sipila, M., Sarnela, N., Junninen, H., Adamov, A., Almeida, J., Amorim, A., Bianchi, F., Breitenlechner, M., Dommen, J., Donahue, N. M., Duplissy, J., Ehrhart, S., Flagan, R. C., Franchin, A., Hakala, J., Hansel, A., Heinritzi, M., Hutterli, M., Kangasluoma, J., Kirkby, J., Laaksonen, A., Lehtipalo, K., Leiminger, M., Makhmutov, V., Mathot, S., Onnela, A., Petaja, T., Praplan, A. P., Riccobono, F., Rissanen, M. P., Rondo, L., Schobesberger, S., Seinfeld, J. H., Steiner, G., Tome, A., Trostl, J., Winkler, P. M., Williamson, C., Wimmer, D., Ye, P. L., Baltensperger, U., Carslaw, K. S., Kulmala, M., Worsnop, D. R., and Curtius, J.: Neutral molecular cluster formation of sulfuric acid-dimethylamine observed in real time under atmospheric conditions, P. Natl. Acad. Sci. USA, 111, 1501915024, https://doi.org/10.1073/pnas.1404853111, 2014.

Kürten, A., Bianchi, F., Almeida, J., Kupiainen-Maatta, O., Dunne, E. M., Duplissy, J., Williamson, C., Barmet, P., Breitenlechner, M., Dommen, J., Donahue, N. M., Flagan, R. C., Franchin, A., Gordon, H., Hakala, J., Hansel, A., Heinritzi, M., Ickes, L., Jokinen, T., Kangasluoma, J., Kim, J., Kirkby, J., Kupc, A., Lehtipalo, K., Leiminger, M., Makhmutov, V., Onnela, A., Ortega, I. K., Petaja, T., Praplan, A. P., Riccobono, F., Rissanen, M. P., Rondo, L., Schnitzhofer, R., Schobesberger, S., Smith, J. N., Steiner, G., Stozhkov, Y., Tome, A., Trostl, J., Tsagkogeorgas, G., Wagner, P. E., Wimmer, D., Ye, P. L., Baltensperger, U., Carslaw, K., Kulmala, M., and Curtius, J.: Experimental particle formation rates spanning tropospheric sulfuric acid and ammonia abundances, ion production rates, and temperatures, J. Geophys. Res.-Atmos., 121, 12377-12400, https://doi.org/10.1002/2015jd023908, 2016.
Kürten, A., Li, C., Bianchi, F., Curtius, J., Dias, A., Donahue, N. M., Duplissy, J., Flagan, R. C., Hakala, J., Jokinen, T., Kirkby, J., Kulmala, M., Laaksonen, A., Lehtipalo, K., Makhmutov, V., Onnela, A., Rissanen, M. P., Simon, M., Sipilä, M., Stozhkov, Y., Tröstl, J., Ye, P., and McMurry, P. H.: New particle formation in the sulfuric acid-dimethylamine-water system: reevaluation of CLOUD chamber measurements and comparison to an aerosol nucleation and growth model, Atmos. Chem. Phys., 18, 845-863, https://doi.org/10.5194/acp-18-845-2018, 2018.

Lelieveld, J., Evans, J. S., Fnais, M., Giannadaki, D., and Pozzer, A.: The contribution of outdoor air pollution sources to premature mortality on a global scale, Nature, 525, 367-371, https://doi.org/10.1038/nature15371, 2015.

Levelt, P. F., Van den Oord, G. H. J., Dobber, M. R., Malkki, A., Visser, H., de Vries, J., Stammes, P., Lundell, J. O. V., and Saari, H.: The Ozone Monitoring Instrument, IEEE T. Geosci. Remote, 44, 1093-1101, https://doi.org/10.1109/Tgrs.2006.872333, 2006.

Li, C., Joiner, J., Krotkov, N. A., and Bhartia, P. K.: A fast and sensitive new satellite $\mathrm{SO}_{2}$ retrieval algorithm based on principal component analysis: Application to the ozone monitoring instrument, Geophys. Res. Lett., 40, 6314-6318, https://doi.org/10.1002/2013gl058134, 2013.

Li, H., Zhang, Q., Zheng, B., Chen, C., Wu, N., Guo, H., Zhang, Y., Zheng, Y., Li, X., and He, K.: Nitrate-driven urban haze pollution during summertime over the North China Plain, Atmos. Chem. Phys., 18, 5293-5306, https://doi.org/10.5194/acp18-5293-2018, 2018.

Lihavainen, H., Alghamdi, M. A., Hyvarinen, A. P., Hussein, T., Aaltonen, V., Abdelmaksoud, A. S., Al-Jeelani, H., Almazroui, M., Almehmadi, F. M., Al Zawad, F. M., Hakala, J., Khoder, M., Neitola, K., Petaja, T., Shabbaj, I. I., and Hameri, K.: Aerosols physical properties at Hada $\mathrm{Al}$ Sham, western Saudi Arabia, Atmos. Environ., 135, 109-117, https://doi.org/10.1016/j.atmosenv.2016.04.001, 2016.

Lihavainen, H., Alghamdi, M. A., Hyvarinen, A. P., Hussein, T., Neitola, K., Khoder, M., Abdelmaksoud, A. S., Al-Jeelani, H., Shabbaj, I. I., and Almehmadi, F. M.: Aerosol optical properties at rural background area in Western Saudi Arabia, Atmos. Res. 197, 370-378, 2017.

Makkonen, R., Asmi, A., Kerminen, V.-M., Boy, M., Arneth, A., Hari, P., and Kulmala, M.: Air pollution control and decreasing new particle formation lead to strong climate warming, Atmos. Chem. Phys., 12, 1515-1524, https://doi.org/10.5194/acp12-1515-2012, 2012.

Merikanto, J., Spracklen, D. V., Mann, G. W., Pickering, S. J., and Carslaw, K. S.: Impact of nucleation on global CCN, Atmos. Chem. Phys., 9, 8601-8616, https://doi.org/10.5194/acp-9-86012009, 2009.

Nie, W., Ding, A. J., Wang, T., Kerminen, V. M., George, C., Xue, L. K., Wang, W. X., Zhang, Q. Z., Petaja, T., Qi, X. M., Gao, X. M., Wang, X. F., Yang, X. Q., Fu, C. B., and Kulmala, M.: Polluted dust promotes new particle formation and growth, Sci Rep.-UK, 4, 6634, https://doi.org/10.1038/srep06634, 2014.

Nieminen, T., Lehtinen, K. E. J., and Kulmala, M.: Sub-10 nm particle growth by vapor condensation - effects of vapor molecule size and particle thermal speed, Atmos. Chem. Phys., 10, 9773 9779, https://doi.org/10.5194/acp-10-9773-2010, 2010. 
Nieminen, T., Asmi, A., Dal Maso, M., Aalto, P. P., Keronen, P., Petaja, T., Kulmala, M., and Kerminen, V. M.: Trends in atmospheric new-particle formation: 16 years of observations in a boreal-forest environment, Boreal Environ. Res., 19, 191-214, 2014.

Nieminen, T., Yli-Juuti, T., Manninen, H. E., Petäjä, T., Kerminen, V.-M., and Kulmala, M.: Technical note: New particle formation event forecasts during PEGASOS-Zeppelin Northern mission 2013 in Hyytiälä, Finland, Atmos. Chem. Phys., 15, 1238512396, https://doi.org/10.5194/acp-15-12385-2015, 2015.

Nieminen, T., Kerminen, V.-M., Petäjä, T., Aalto, P. P., Arshinov, M., Asmi, E., Baltensperger, U., Beddows, D. C. S., Beukes, J. P., Collins, D., Ding, A., Harrison, R. M., Henzing, B., Hooda, R., Hu, M., Hõrrak, U., Kivekäs, N., Komsaare, K., Krejci, R., Kristensson, A., Laakso, L., Laaksonen, A., Leaitch, W. R., Lihavainen, H., Mihalopoulos, N., Németh, Z., Nie, W., O’Dowd, C., Salma, I., Sellegri, K., Svenningsson, B., Swietlicki, E., Tunved, P., Ulevicius, V., Vakkari, V., Vana, M., Wiedensohler, A., Wu, Z., Virtanen, A., and Kulmala, M.: Global analysis of continental boundary layer new particle formation based on longterm measurements, Atmos. Chem. Phys., 18, 14737-14756, https://doi.org/10.5194/acp-18-14737-2018, 2018.

Paasonen, P., Nieminen, T., Asmi, E., Manninen, H. E., Petäjä, T., Plass-Dülmer, C., Flentje, H., Birmili, W., Wiedensohler, A., Hõrrak, U., Metzger, A., Hamed, A., Laaksonen, A., Facchini, M. C., Kerminen, V.-M., and Kulmala, M.: On the roles of sulphuric acid and low-volatility organic vapours in the initial steps of atmospheric new particle formation, Atmos. Chem. Phys., 10, 11223-11242, https://doi.org/10.5194/acp-10-112232010, 2010.

Pierce, J. R. and Adams, P. J.: Uncertainty in global CCN concentrations from uncertain aerosol nucleation and primary emission rates, Atmos. Chem. Phys., 9, 1339-1356, https://doi.org/10.5194/acp-9-1339-2009, 2009.

Riccobono, F., Rondo, L., Sipilä, M., Barmet, P., Curtius, J., Dommen, J., Ehn, M., Ehrhart, S., Kulmala, M., Kürten, A., Mikkilä, J., Paasonen, P., Petäjä, T., Weingartner, E., and Baltensperger, U.: Contribution of sulfuric acid and oxidized organic compounds to particle formation and growth, Atmos. Chem. Phys., 12, 9427-9439, https://doi.org/10.5194/acp-129427-2012, 2012.

Riccobono, F., Schobesberger, S., Scott, C. E., Dommen, J., Ortega, I. K., Rondo, L., Almeida, J., Amorim, A., Bianchi, F., Breitenlechner, M., David, A., Downard, A., Dunne, E. M., Duplissy, J., Ehrhart, S., Flagan, R. C., Franchin, A., Hansel, A., Junninen, H., Kajos, M., Keskinen, H., Kupc, A., Kurten, A., Kvashin, A. N., Laaksonen, A., Lehtipalo, K., Makhmutov, V., Mathot, S., Nieminen, T., Onnela, A., Petaja, T., Praplan, A. P., Santos, F. D., Schallhart, S., Seinfeld, J. H., Sipila, M., Spracklen, D. V., Stozhkov, Y., Stratmann, F., Tome, A., Tsagkogeorgas, G., Vaattovaara, P., Viisanen, Y., Vrtala, A., Wagner, P. E., Weingartner, E., Wex, H., Wimmer, D., Carslaw, K. S., Curtius, J., Donahue, N. M., Kirkby, J., Kulmala, M., Worsnop, D. R., and Baltensperger, U.: Oxidation Products of Biogenic Emissions Contribute to Nucleation of Atmospheric Particles, Science, 344, 717-721, https://doi.org/10.1126/science.1243527, 2014.

Salma, I., Németh, Z., Weidinger, T., Kovács, B., and Kristóf, G.: Measurement, growth types and shrinkage of newly formed aerosol particles at an urban research platform, At- mos. Chem. Phys., 16, 7837-7851, https://doi.org/10.5194/acp16-7837-2016, 2016.

Seibert, P. and Frank, A.: Source-receptor matrix calculation with a Lagrangian particle dispersion model in backward mode, Atmos. Chem. Phys., 4, 51-63, https://doi.org/10.5194/acp-4-512004, 2004.

Seinfeld, J. H. and Pandis, S. N.: Atmospheric chemistry and physics: from air pollution to climate change, Wiley, New York, 1326 pp., 1998.

Semeniuk, K. and Dastoor, A.: Current state of aerosol nucleation parameterizations for air-quality and climate modeling, Atmos. Environ., 179, 77-106, https://doi.org/10.1016/j.atmosenv.2018.01.039, 2018.

Sipilä, M., Sarnela, N., Jokinen, T., Henschel, H., Junninen, H., Kontkanen, J., Richters, S., Kangasluoma, J., Franchin, A., Perakyla, O., Rissanen, M. P., Ehn, M., Vehkamaki, H., Kurten, T., Berndt, T., Petaja, T., Worsnop, D., Ceburnis, D., Kerminen, V. M., Kulmala, M., and O'Dowd, C.: Molecular-scale evidence of aerosol particle formation via sequential addition of $\mathrm{HIO}_{3}, \mathrm{Na}-$ ture, 537, 532-534, https://doi.org/10.1038/nature19314, 2016.

Skrabalova, L.: Shrinkage of Newly Formed Particles in an Urban Environment, Aerosol Air Qual. Res., 15, 1313-1324, https://doi.org/10.4209/aaqr.2015.01.0015, 2015.

Smith, J. N., Dunn, M. J., VanReken, T. M., Iida, K., Stolzenburg, M. R., McMurry, P. H., and Huey, L. G.: Chemical composition of atmospheric nanoparticles formed from nucleation in Tecamac, Mexico: Evidence for an important role for organic species in nanoparticle growth, Geophys. Res. Lett., 35, L04808, https://doi.org/10.1029/2007gl032523, 2008.

Stocker, T. F., Qin, D., Plattner, G.-K., Alexander, L. V., Allen, S. K., Bindoff, N. L., Breìon, F.-M., Church, J. A., Cubasch, U., Emori, S., Forster, P., Friedlingstein, P., Gillett, N., Gregory, J. M., Hartmann, D. L., Jansen, E., Kirtman, B., Knutti, R., Krishna Kumar, K., Lemke, P., Marotzke, J., Masson-Delmotte, V., Meehl, G. A., Mokhov, I. I., Piao, S., Ramaswamy, V., Randall, D., Rhein, M., Rojas, M., Sabine, C., Shindell, D., Talley, L. D., Vaughan, D. G., and Xie, S.-P.: Climate Change 2013: The Physical Science Basis. Contribution of Working Group I to the Fifth Assessment Report of the Intergovernmental Panel on Climate Change, Technical summary, edited by: Stocker, T. F., Qin, D., Plattner, G.-K., Tignor, M., Allen, S. K., Boschung, J., Nauels, A., Xia, Y., Bex, V., and Midgley, P. M., Cambridge University Press, Cambridge, United Kingdom and New York, NY, USA, 2013.

Stohl, A., Forster, C., Frank, A., Seibert, P., and Wotawa, G.: Technical note: The Lagrangian particle dispersion model FLEXPART version 6.2, Atmos. Chem. Phys., 5, 2461-2474, https://doi.org/10.5194/acp-5-2461-2005, 2005.

Tröstl, J., Chuang, W. K., Gordon, H., Heinritzi, M., Yan, C., Molteni, U., Ahlm, L., Frege, C., Bianchi, F., Wagner, R., Simon, M., Lehtipalo, K., Williamson, C., Craven, J. S., Duplissy, J., Adamov, A., Almeida, J., Bernhammer, A. K., Breitenlechner, M., Brilke, S., Dias, A., Ehrhart, S., Flagan, R. C., Franchin, A., Fuchs, C., Guida, R., Gysel, M., Hansel, A., Hoyle, C. R., Jokinen, T., Junninen, H., Kangasluoma, J., Keskinen, H., Kim, J., Krapf, M., Kurten, A., Laaksonen, A., Lawler, M., Leiminger, M., Mathot, S., Mohler, O., Nieminen, T., Onnela, A., Petaja, T., Piel, F. M., Miettinen, P., Rissanen, M. P., Rondo, L., Sarnela, N., Schobesberger, S., Sengupta, K., Sip- 
ila, M., Smith, J. N., Steiner, G., Tome, A., Virtanen, A., Wagner, A. C., Weingartner, E., Wimmer, D., Winkler, P. M., Ye, P., Carslaw, K. S., Curtius, J., Dommen, J., Kirkby, J., Kulmala, M., Riipinen, I., Worsnop, D. R., Donahue, N. M., and Baltensperger, U.: The role of low-volatility organic compounds in initial particle growth in the atmosphere, Nature, 533, 527-531, https://doi.org/10.1038/nature18271, 2016.

Usher, C. R., Michel, A. E., and Grassian, V. H.: Reactions on mineral dust, Chem. Rev., 103, 4883-4939, https://doi.org/10.1021/cr020657y, 2003.

Vakkari, V., Laakso, H., Kulmala, M., Laaksonen, A., Mabaso, D., Molefe, M., Kgabi, N., and Laakso, L.: New particle formation events in semi-clean South African savannah, Atmos. Chem. Phys., 11, 3333-3346, https://doi.org/10.5194/acp-113333-2011, 2011.

Vakkari, V., Tiitta, P., Jaars, K., Croteau, P., Beukes, J. P., Josipovic, M., Kerminen, V. M., Kulmala, M., Venter, A. D., van Zyl, P. G., Worsnop, D. R., and Laakso, L.: Reevaluating the contribution of sulfuric acid and the origin of organic compounds in atmospheric nanoparticle growth, Geophys. Res. Lett., 42, 1048610493, https://doi.org/10.1002/2015gl066459, 2015.

Weber, R. J., Marti, J. J., McMurry, P. H., Eisele, F. L., Tanner, D. J., and Jefferson, A.: Measurements of new particle formation and ultrafine particle growth rates at a clean continental site, J. Geophys. Res.-Atmos., 102, 4375-4385, https://doi.org/10.1029/96jd03656, 1997.

Wiedensohler, A., Birmili, W., Nowak, A., Sonntag, A., Weinhold, K., Merkel, M., Wehner, B., Tuch, T., Pfeifer, S., Fiebig, M., Fjäraa, A. M., Asmi, E., Sellegri, K., Depuy, R., Venzac, H., Villani, P., Laj, P., Aalto, P., Ogren, J. A., Swietlicki, E., Williams, P., Roldin, P., Quincey, P., Hüglin, C., Fierz-Schmidhauser, R., Gysel, M., Weingartner, E., Riccobono, F., Santos, S., Grüning, C., Faloon, K., Beddows, D., Harrison, R., Monahan, C., Jennings, S. G., O’Dowd, C. D., Marinoni, A., Horn, H.-G., Keck, L., Jiang, J., Scheckman, J., McMurry, P. H., Deng, Z., Zhao, C. S., Moerman, M., Henzing, B., de Leeuw, G., Löschau, G., and Bastian, S.: Mobility particle size spectrometers: harmonization of technical standards and data structure to facilitate high quality long-term observations of atmospheric particle number size distributions, Atmos. Meas. Tech., 5, 657-685, https://doi.org/10.5194/amt-5-657-2012, 2012.

Xie, Y. N., Ding, A. J., Nie, W., Mao, H. T., Qi, X. M., Huang, X., Xu, Z., Kerminen, V. M., Petaja, T., Chi, X. G., Virkkula, A., Boy, M., Xue, L. K., Guo, J., Sun, J. N., Yang, X. Q., Kulmala, M., and Fu, C. B.: Enhanced sulfate formation by nitrogen dioxide: Implications from in situ observations at the SORPES station, J. Geophys. Res.-Atmos., 120, 12679-12694, https://doi.org/10.1002/2015jd023607, 2015.

Yao, L., Garmash, O., Bianchi, F., Zheng, J., Yan, C., Kontkanen, J., Junninen, H., Mazon, S. B., Ehn, M., Paasonen, P., Sipila, M., Wang, M. Y., Wang, X. K., Xiao, S., Chen, H. F., Lu, Y. Q., Zhang, B. W., Wang, D. F., Fu, Q. Y., Geng, F. H., Li, L., Wang, H. L., Qiao, L. P., Yang, X., Chen, J. M., Kerminen, V. M., Petaja, T., Worsnop, D. R., Kulmala, M., and Wang, L.: Atmospheric new particle formation from sulfuric acid and amines in a Chinese megacity, Science, 361, 278-281, https://doi.org/10.1126/science.aao4839, 2018.
Yao, X. H., Choi, M. Y., Lau, N. T., Lau, A. P. S., Chan, C. K., and Fang, M.: Growth and Shrinkage of New Particles in the Atmosphere in Hong Kong, Aerosol Sci. Technol., 44, 639-650, https://doi.org/10.1080/02786826.2010.482576, 2010.

Yli-Juuti, T., Nieminen, T., Hirsikko, A., Aalto, P. P., Asmi, E., Hõrrak, U., Manninen, H. E., Patokoski, J., Dal Maso, M., Petäjä, T., Rinne, J., Kulmala, M., and Riipinen, I.: Growth rates of nucleation mode particles in Hyytiälä during 20032009: variation with particle size, season, data analysis method and ambient conditions, Atmos. Chem. Phys., 11, 12865-12886, https://doi.org/10.5194/acp-11-12865-2011, 2011.

Young, L.-H., Lee, S.-H., Kanawade, V. P., Hsiao, T.-C., Lee, Y. L., Hwang, B.-F., Liou, Y.-J., Hsu, H.-T., and Tsai, P.-J.: New particle growth and shrinkage observed in subtropical environments, Atmos. Chem. Phys., 13, 547-564, https://doi.org/10.5194/acp13-547-2013, 2013.

Yu, F. and Luo, G.: Simulation of particle size distribution with a global aerosol model: contribution of nucleation to aerosol and CCN number concentrations, Atmos. Chem. Phys., 9, 76917710, https://doi.org/10.5194/acp-9-7691-2009, 2009.

Yu, F., Nadykto, A. B., Herb, J., Luo, G., Nazarenko, K. M., and Uvarova, L. A.: $\mathrm{H}_{2} \mathrm{SO}_{4}-\mathrm{H}_{2} \mathrm{O}-\mathrm{NH}_{3}$ ternary ion-mediated nucleation (TIMN): kinetic-based model and comparison with CLOUD measurements, Atmos. Chem. Phys., 18, 17451-17474, https://doi.org/10.5194/acp-18-17451-2018, 2018.

Yu, H., McGraw, R., and Lee, S. H.: Effects of amines on formation of sub-3 nm particles and their subsequent growth, Geophys. Res. Lett., 39, L02807, https://doi.org/10.1029/2011g1050099, 2012.

Yu, H., Ren, L. L., and Kanawade, V. P.: New Particle Formation and Growth Mechanisms in Highly Polluted Environments, Curr. Pollut. Rep., 3, 245-253, https://doi.org/10.1007/s40726017-0067-3, 2017.

Yue, D. L., Hu, M., Zhang, R. Y., Wu, Z. J., Su, H., Wang, Z. B., Peng, J. F., He, L. Y., Huang, X. F., Gong, Y. G., and Wiedensohler, A.: Potential contribution of new particle formation to cloud condensation nuclei in Beijing, Atmos. Environ., 45, 6070-6077, https://doi.org/10.1016/j.atmosenv.2011.07.037, 2011.

Zhang, J., Chen, Z., Lu, Y., Gui, H., Liu, J., Wang, J., Yu, T., and Cheng, Y.: Observations of New Particle Formation, Subsequent Growth and Shrinkage during Summertime in Beijing, Aerosol Air Qual. Res., 16, 1591-1602, https://doi.org/10.4209/aaqr.2015.07.0480, 2016.

Zhang, R. Y., Suh, I., Zhao, J., Zhang, D., Fortner, E. C., Tie, X. X., Molina, L. T., and Molina, M. J.: Atmospheric new particle formation enhanced by organic acids, Science, 304, 1487-1490, https://doi.org/10.1126/science.1095139, 2004. 